\title{
Synchronized Oscillations in Hippocampal CA3 Neurons Induced by Metabotropic Glutamate Receptor Activation
}

\author{
Gregory W. Taylor,' Lisa R. Merlin,, ${ }^{1,2}$ and Robert K. S. Wong ${ }^{1,2}$ \\ Departments of ${ }^{1}$ Pharmacology and ${ }^{2}$ Neurology, State University of New York Health Science Center at Brooklyn, \\ Brooklyn, New York 11203
}

The metabotropic glutamate receptor agonist (1S,3R)-1aminocyclopentane-1,3 dicarboxylic acid (ACPD) at concentrations above $60 \mu \mathrm{M}$ produced stereotypic oscillatory activity in CA3 pyramidal cells of rat hippocampal slices. This oscillatory activity consisted of trains of depolarizations with overriding action potentials. On average, individual trains lasted $7 \mathrm{sec}$ and recurred at intervals of $24 \mathrm{sec}$. During each train, the constituent depolarizations achieved a maximum frequency of $27 \mathrm{~Hz}$, then slowed to $8 \mathrm{~Hz}$ toward the end of the train. Extracellular and dual intracellular recordings suggested that this ACPD-induced oscillatory activity occurred synchronously in the CA3 population. The oscillations persisted in the presence of $\mathrm{GABA}_{A}, \mathrm{GABA}_{B}$, and NMDA receptor antagonists. In contrast, the oscillations were blocked by the AMPA/kainate receptor antagonist 6-cyano-7-nitroquinoxaline-2,3-dione (CNQX; 10-30 $\mu M)$. Likewise, the oscillations were blocked by the metabotropic glutamate receptor antagonists (+)- $\alpha$-methyl-4carboxyphenylglycine [(+)-MCPG; $1 \mathrm{~mm}$ ], (S)-4-carboxy-3hydroxyphenylglycine [(S)-4C3HPG; $1 \mathrm{~mm}$ ] and (S)-4-carboxyphenylglycine [(S)-4CPG; $1 \mathrm{~mm}$ ]. The results suggest that activation of metabotropic glutamate receptors can result in a permissive state that allows AMPA/kainate receptor-mediated conductances to mediate synchronized activity among hippocampal CA3 neurons.

[Key words: glutamate, metabotropic glutamate receptor, synapse, ACPD, archaeocortex, hippocampus, synchrony, oscillations, excitatation, inhibition, rhythm, intracellular recordings]

Metabotropic glutamate receptor (mGluR) activation is involved in the generation of distinct patterns of synchronized activity in the hippocampus. Direct activation of mGluRs with ACPD is reported to induce seizures in vivo (Sacaan and Schoepp, 1992), and can modulate the in vitro epileptiform activities elicited by application of $\mathrm{GABA}_{\mathrm{A}}$ receptor antagonists (Burke and Hablitz, 1995; Merlin et al., 1995) or by tetanic stimulation of afferent fibers (Liu et al., 1993). Activation of mGluRs has recently been demonstrated to result in the expression of $40 \mathrm{~Hz}$ synchronized

\footnotetext{
Received May 26, 1995; revised Aug. 7, 1995; accepted Aug. 14, 1995.

This work was supported by the National Institutes of Health. We thank our colleagues R. Miles, R. Muller, K. Perkins, J. B. Ranck, Jr., M. Stewart, and R. D. Traub for helpful discussions and remarks on earlier versions of the manuscript.

Correspondence should be addressed to G. W. Taylor, Department of Pharmacology, Box 29, State University of New York Health Science Center at Brooklyn, 450 Clarkson Avenue, Brooklyn, NY'11203.

Copyright (C) 1995 Society for Neuroscience 0270-6474/95/158039-14\$05.00/0
}

oscillations in inhibitory neurons in the presence of ionotropic glutamate receptor antagonists (Whittington et al., 1995). In this article, we introduce a new phenomenon that is elicited by in tense activation of mGluRs. The phenomenon consists of a stereotypic pattern of synchronized oscillation which occurs spontaneously in hippocampal CA3 neurons in the presence of ACPD.

The mGluRs include at least seven receptor subtypes (Abe et al., 1992; Shigemoto et al., 1992; Akazawa et al., 1994; Ohishi et al., 1994). The first group to be recognized includes mGluRs 1 and 5 which are coupled to phosphoinositide (PI) hydrolysis (Houamed et al., 1991; Masu et al., 1991; Abe et al., 1992; Baude et al., 1993). With the exception of mGluR 6 , the other mGluRs (subtypes 2 and 3; 4, 7, and possibly 8) are negatively coupled to cyclic AMP formation (Nawy and Jahr, 1991; Tanabe et al., 1992, 1993; Winder and Conn, 1992; Cartmell et al., 1993a, 1994; Duvoisin et al., 1995). Most mGluRs respond to ACPD (Schoepp and Conn, 1993; Chung et al., 1994); however, mGluRs 2 and 3 can be selectively activated by L-2-(2,3-dicarboxycyclopropyl)glycine (DCG-IV; Ohfune et al., 1993; Poncer et al., 1995), while mGluRs 4, 6, and 7 are selectively activated by $\mathrm{L}(+)$-2-amino-4-phosphonobutyric acid (L-AP4; Akazawa et al., 1994).

Previous studies of mGluRs have emphasized their roles in phenomena such as synaptic plasticity and excitotoxicity (Ito and Sugiyama,1991; McDonald and Schoepp, 1993; Schoepp and Conn, 1993; Bolshakov and Siegelbaum, 1994; Bortolotto et al., 1994). In addition, activation of mGluRs might be expected to promote synchronized discharges by facilitating excitability and diminishing inhibition (Desai and Conn, 1991; Glaum and Miller, 1993). The excitatory effects of mGluR activation include membrane depolarization secondary to suppression of potassium conductances (Charpak et al., 1990; Stratton et al., 1990; Charpak and Gähwiler, 1991; Miles and Poncer, 1993), induction of burst firing (Zheng and Gallagher, 1991), and potentiation of an afterdepolarization (Constanti and Libri, 1992; Zheng and Gallagher, 1992; Greene et al., 1994). Activation of presynaptic mGluRs can suppress inhibitory synaptic transmission (Hayashi et al., 1994a) by decreasing GABA release (Poncer et al., 1995). However, activation of presynaptic mGluRs can also suppress calcium currents and excitatory synaptic transmission (Forsythe and Clements, 1990; Lester and Jahr, 1990; Baskys and Malenka, 1991; Trombley and Westbrook, 1992; Schoepp and Conn, 1993; Sladeczek et al., 1993).

In this article, we begin to address the generation mechanisms of ACPD-induced oscillations by identifying the synaptic components necessary for its expression. We have also attempted to 
evaluate the involvement of mGluR subtypes by utilizing selective phenylglycine derivatives with agonist and antagonist activities at specific mGluR subclasses (Hayashi, 1994b; Watkins and Collingridge, 1994).

A preliminary version of these findings has been reported in abstract form (Taylor and Wong, 1994).

\section{Materials and Methods}

Slice preparation and chamber conditions. Sprague-Dawley rats (15$80 \mathrm{~d}$ old) of both sexes were anesthetized with halothane, then surgically decapitated. Brains were placed in ice cold medium containing $0.5 \mathrm{~mm} \mathrm{Ca}^{2+}$ and $8 \mathrm{~mm} \mathrm{Mg}^{2+}$ (low $\mathrm{Ca}^{2+} /$ high $\mathrm{Mg}^{2+}$ solution) for $1 \mathrm{~min}$, then $400 \mu \mathrm{m}$ transverse sections were sliced from the right hippocampus using a Vibratome (Technical Products International). Slices were then placed on nylon netting in a recording chamber (QL-2, Fine Science Tools) where they were perfused from below with control medium containing (in mM) Na ${ }^{+} 149, \mathrm{Cl}^{-} 136, \mathrm{~K}^{+} 5, \mathrm{Mg}^{2+} 1.6, \mathrm{Ca}^{2+} 2, \mathrm{HCO}_{3}^{-} 26$, $\mathrm{H}_{2} \mathrm{PO}_{4}^{-} 1.25$, and glucose 11 . Perfusion media were bubbled with $95 \%$ $\mathrm{O}_{2} / 5 \% \mathrm{CO}_{2}$ to maintain the $\mathrm{pH}$ near 7.4. The same gas mixture, warmed and humidified, provided the environment for the upper surfaces of the slices. Slices were continuously perfused at $0.2-0.4 \mathrm{ml} / \mathrm{min}$ while the chamber was maintained at $34-36^{\circ} \mathrm{C}$ (TCU-2, Fine Science Tools). Recordings began after 1-2 hr of equilibration for experiments of 2-12 hr duration. Stratum pyramidale was visualized through an upright binocular microscope (SMZ-2B, Nikon) with illumination (Cole Parmer Instruments) from above. ACPD-induced oscillations seemed to be most reliably elicited from slices obtained from the middle one-third of the hippocampus from animals $24.40 \mathrm{~d}$ old. Animal care was in accordance with responsible and humane treatment guidelines approved by the U.S. Public Health Service Policy on Humane Care and Use of Laboratory Animals, the National Institutes of Health Guide for the Care and Use of Laboratory Animals, and the New York State Department of Health.

Materials. Inorganic salts, glucose, picrotoxin, bicuculline, tetrodotoxin, and halothane were purchased from Sigma. ACPD, L-CCG-, CNQX, 3-(RS-2-carboxypiperazin-4-yl)-propyl-1-phosphonic acid (CPP), 2-hydroxysaclofen, (+)-MCPG, $(S)$-4C3HPG, and (S)-4CPG were purchased from Tocris Neuramin (Bristol, UK) or Research Biochemicals Inc. A generous gift of CGP 35348 was provided by CibaGeigy.

Electrophysiological recordings. Electrodes for intracellular and extracellular recording were pulled from glass $(1.0 \mathrm{~mm}$ O.D., with filament, World Precision Instruments) on a micropipette puller (Sutter Instruments). Intracellular recording electrodes were filled with $2 \mathrm{M}$ potassium acetate; extracellular electrodes were filled with $2 \mathrm{M} \mathrm{NaCl}$. Intracellular electrodes were beveled (Sutter Instruments) to a final tip resistance of 20-110 M $\Omega$. Extracellular electrodes were less than $5 \mathrm{M} \Omega$. Signals from current-clamp recordings were amplified (model M-707; World Precision Instruments; bandpass, 1-30 kHz or wide band) and displayed simultaneously on an IBM-compatible computer running pCLAMP software (Axon Instruments), an oscilloscope (model 2160, BK Precision), and a chart recorder (model TA240, Gould). Data were acquired at a gain of 20 at $0.2-240 \mathrm{msec}$ per point, and stored on disk for oft-line analysis. Input resistance was monitored by delivering 0.5 $\mathrm{Hz}, 0.6 \mathrm{nA}, 50-500 \mathrm{msec}$ D.C. current injections (PG-4000 digital stimulator, Neurodata Instruments) through the intracellular recording electrode. Electrodes were placed within about $1.5 \mathrm{~mm}$ of each other for dual recordings.

Characterization of train duration. intertrain interval, and depolarization frequency. Data analysis for normative values was limited to 10 experiments in which animals were $22-31 \mathrm{~d}$ old, ACPD concentrations of $100-200 \mathrm{M}$ were used, and continuous digital records $(1.6 \mathrm{msec}$ per point; Fetchex, pCLAMP software) were available for six consecutive trains after at least 20 , but less than 50 , full cycles of recurring trains, and before any other pharmacological manipulation. In the case of drop application, data analysis was limited to seven experiments using $5 \mathrm{~mm}$ drops of ACPD, and where digital records (1.6 msec per point; Fetchex, pCLAMP software) were available after at least two repeated applications, but before any other pharmacological manipulation. Data analysis across slices was derived from the medians of individual slices and reported as mean \pm interslice standard deviation. Intertrain intervals were measured from the start of one train to the start of the next. To analyze the effect of GABA antagonists, $t$ tests were used to compare 46 trains from six slices. For each slice, we determined the median frequency and intertrain quiescent period (from the end of one train to the start of the next) for four to six consecutive trains before and after antagonist application. Mean values from each slice were used for interslice comparisons using paired $t$ tests, with final values reported in the text as the mean of means \pm SEM.

Drug delivery. Pharmacological agents from concentrated stock solutions were applied to the perfusion media with dilutions of 10-2000 or more. Media of altered ionic compositions were applied isosmotically to the perfusion system with observable effects occurring in 3-9 min Methods of drug delivery included continuous perfusion, transient bath application, or focal drop application. Continuous perfusion with 200 $\mu \mathrm{M}$ ACPD usually produced the oscillations. Depending on flow rate and length and diameter of perfusion tubing, the latency to an observable response to ACPD ranged from 3 to $9 \mathrm{~min}$ for continuous perfusion. Transient bath applications were carried out by Eppendorf microapplication directly to the bath $(12 \mu \mathrm{l}$ drops from $25 \mathrm{~mm}$ stock, with a well volume of $1.55 \mathrm{ml}$, yielded an estimated "initial" concentration of $200 \mu \mathrm{M}$ ). The latency to characteristic ACPD effects via transient bath application ranged from $15-40 \mathrm{sec}$. Focal drop application of ACPD (200-350 $\mu \mathrm{l}, 5 \mathrm{~mm})$ most reliably provoked the ACPD-dependent oscillations. Drops were focally applied with a plastic syringe (previously heated and pulled to a thin tip) so that the applied media covered $1-3 \mathrm{~mm}$ of CA3. The latency to characteristic ACPD effects in response to drop application ranged from $1-5 \mathrm{sec}$. Drop application usually required repetitive application as is required in other systems (Cherubini et al., 1991; Sciancalepore et al., 1993). In experiments aimed at examining synaptic transmission and the role of amino acid receptor subtypes, three approaches were used: (1) test media (low $\mathrm{Ca}^{2+} / \mathrm{high}_{\mathrm{Mg}}^{2+}$, tetrodotoxin, or amino acid receptor antagonists) were continuously perfused for 20-120 min, and then ACPD was introduced by drop application or by addition to the test media. (2) Transient ACPD-induced oscillations were first evoked by drop application during continuous perfusion with control medium, and then following the introduction of and continuous perfusion with test media, ACPD was reapplied by drop application. (3) Ongoing oscillations were maintained by continuous perfusion with ACPD (100-200 $\mu \mathrm{M})$ in control medium, and then the test media (with ACPD, 100-200 $\mu \mathrm{M}$ ) were introduced.

\section{Results}

Data are derived from intracellular recordings obtained from 297 neurons from 189 slices. Included among the intracellular records are 63 dual recordings from CA3 neurons from 38 slices, 12 recordings from $\mathrm{CA} 1$ neurons in whole slices, 5 from CA1 "mini slices" (CA1 slices with CA2, CA3, and dentate removed), and 4 from CA3 "mini slices" (CA3 slices with CA2, $\mathrm{CA} 1$, and dentate removed). Nineteen extracellular recordings were obtained from the $\mathrm{CA} 3$ and $\mathrm{CAl}$ regions within stratum pyramidale.

\section{Effects of $A C P D$ on $C A 3$ neurons}

Bath perfusion of ACPD (100-200 $\mu \mathrm{M})$ induced spontaneous oscillatory activity in hippocampal neurons (Figs. 1, 2). This activity consisted of trains of depolarizations with overriding action potentials. The trains recurred at regular intervals (Fig. $1 A)$. In a given experiment, the durations of the first few trains elicited by ACPD and the intervals between them were highly variable. With continued perfusion, the variability decreased and the oscillations settled into a more stereotypic pattern (Fig. 2) which could be maintained for up to $8 \mathrm{hr}$. In 10 slices, the train duration was $7.4 \pm 4.1 \mathrm{sec}$ (mean $\pm \mathrm{SD}$ ). The intertrain interval was $24.8 \pm 10.1 \mathrm{sec}(\approx 0.04 \mathrm{~Hz})$. The depolarizations (with overriding action potentials) within each train reached frequencies of $27.4 \pm 6.0 \mathrm{~Hz}$ early in the train, then slowed to $7.8+$ $3.5 \mathrm{~Hz}$, and had a median frequency of $15.3 \pm 1.0 \mathrm{~Hz}$.

Similar activity was transiently evoked by focal drop application of ACPD (200-350 $\mu \mathrm{l}, 5 \mathrm{~mm})$. In seven slices, focal application of ACPD elicited $17.1 \pm 4.8$ cycles (start of one train to the start of the next) of activity lasting $5.4 \pm 1.2 \mathrm{~min}$. This activity consisted of trains lasting $4.8 \pm 1.2 \mathrm{sec}$. The trains 
A

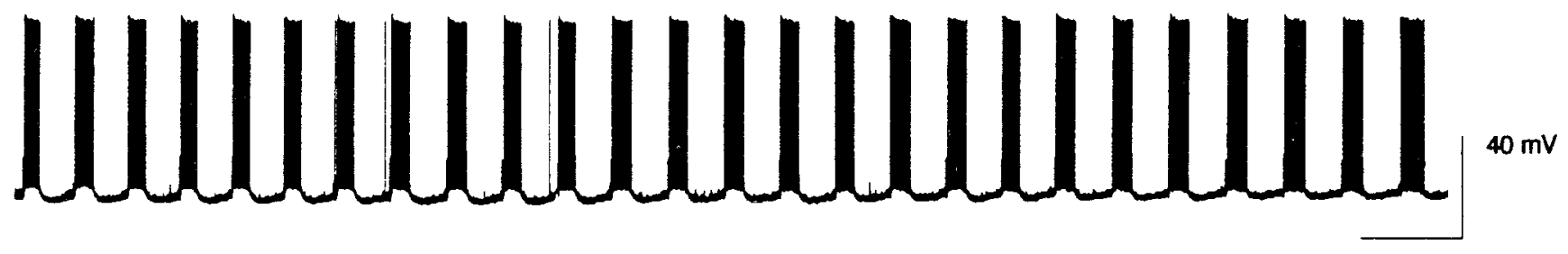

B

$30 \mathrm{~s}$

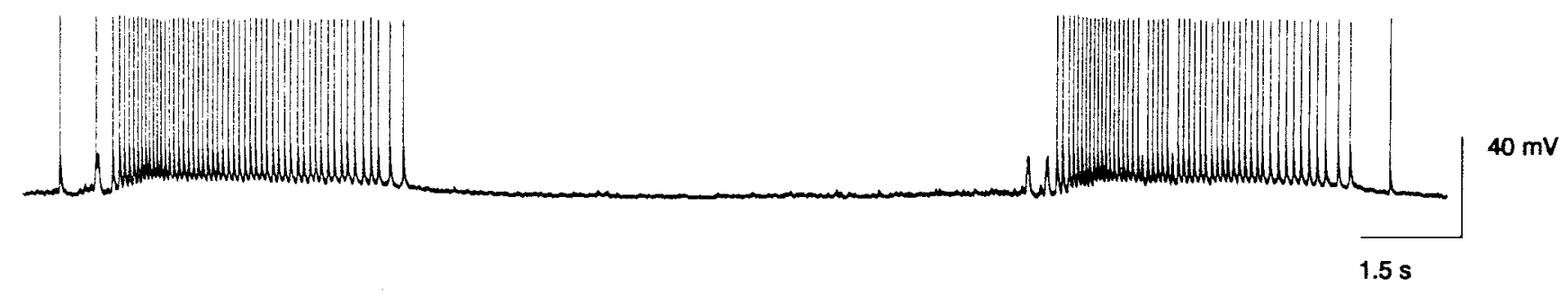

C

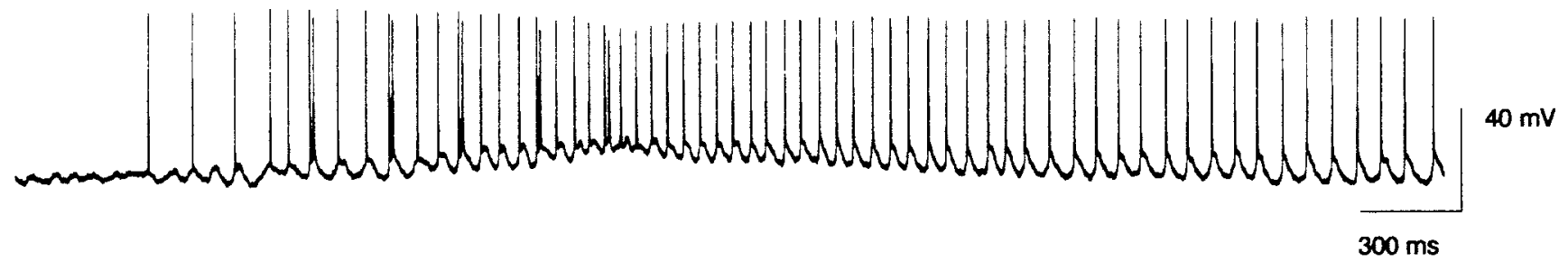

Figure 1. ACPD-induced oscillatory activity recorded intracellularly from CA3 cells. A, Perfusion with ACPD (200 $\mu \mathrm{M})$ produced a stereotypic pattern of oscillation. The oscillations consisted of rhythmically recurring trains of activity. $B$, Two consecutive trains at a faster chart recording speed. $C$, Trains consisted of repetitive depolarizations with overriding action potentials.

recurred at intervals of $16.0 \perp 4.9$ sec. The depolarizations within these trains began at frequencies as high as $38 \mathrm{~Hz}$ and slowed to frequencies as low as $3 \mathrm{~Hz}$.

\section{Effects of hyperpolarization on ACPD-induced oscillatory activity}

Injection of hyperpolarizing current suppressed the action potentials within a train and uncovered the underlying depolarizations (Fig. 3A,B). Further hyperpolarization progressively increased the amplitude of the depolarizations (Fig. 3C). Neither hyperpolarization nor the absence of action potentials had an obvious influence on the intertrain or interdepolarization interval.

\section{ACPD-induced oscillatory activity is synchronized}

When ACPD-induced oscillations were elicited in a slice, the activity was observed in all cells impaled in the CA3 region. Figure 4 shows that significant extracellular voltage deflections could be recorded during the oscillatory events, suggesting that the activity occurred simultaneously in a large number of local ncurons. Dual CA3 pyramidal cell recordings showed ACPDinduced oscillations were synchronized in each instance $(n=$ 63; Fig. 5). Included with these experiments are dual recordings in which one of the pair of intracellular recording electrodes was maintained in a given cell while the other electrode was moved to two to five different sites to record from different cells within the CA3 region ( $n=28$ cells, 7 slices). Synchronous oscillatory activity was observed between the simultaneously recorded cells with each successive impalement.

\section{ACPD-induced oscillations depend on synaptic activity}

To assess mechanisms involved in the generation of ACPD-induced oscillations, slices were perfused with low $\mathrm{Ca}^{2+} /$ high $\mathrm{Mg}^{2+}$ medium which is expected to block chemical synaptic transmission (Schwartzkroin and Prince, 1978). With control perfusion medium, focal application of ACPD produced oscillatory activity in response to each of nine applications $(n=4$ slices; Fig. 6A). After switching to low $\mathrm{Ca}^{2+} /$ high $\mathrm{Mg}^{2+}$ medium, ACPD failed to produce the oscillations in response to each of eight drop applications to the above slices (Fig. 6B). Upon returning to control perfusion, a single drop of ACPD evoked stereotypical oscillatory activity in each instance (Fig. 6C). Additionally, during tonic perfusion with ACPD, ongoing oscillations were reversibly blocked by low $\mathrm{Ca}^{2+} / \mathrm{high}^{\mathrm{Mg}^{2+}}$ medium $(n=5$ slices $)$.

Further evidence that neuron-to-neuron signaling plays a role in generating these ACPD-induced oscillations was provided by experiments with the sodium channel blocker tetrodotoxin (TTX). Prior to adding TTX $(1-2 \mu \mathrm{M})$ to the perfusion medium, focal application of ACPD produced a transient period of oscillatory activity in response to each of 11 applications $(n=6$ slices; Fig. 7A). Once TTX had blocked spontaneously occurring action potentials, ACPD application did not initiate oscillatory activity in response to any of eleven applications (Fig. $7 B$ ). Ad- 
A
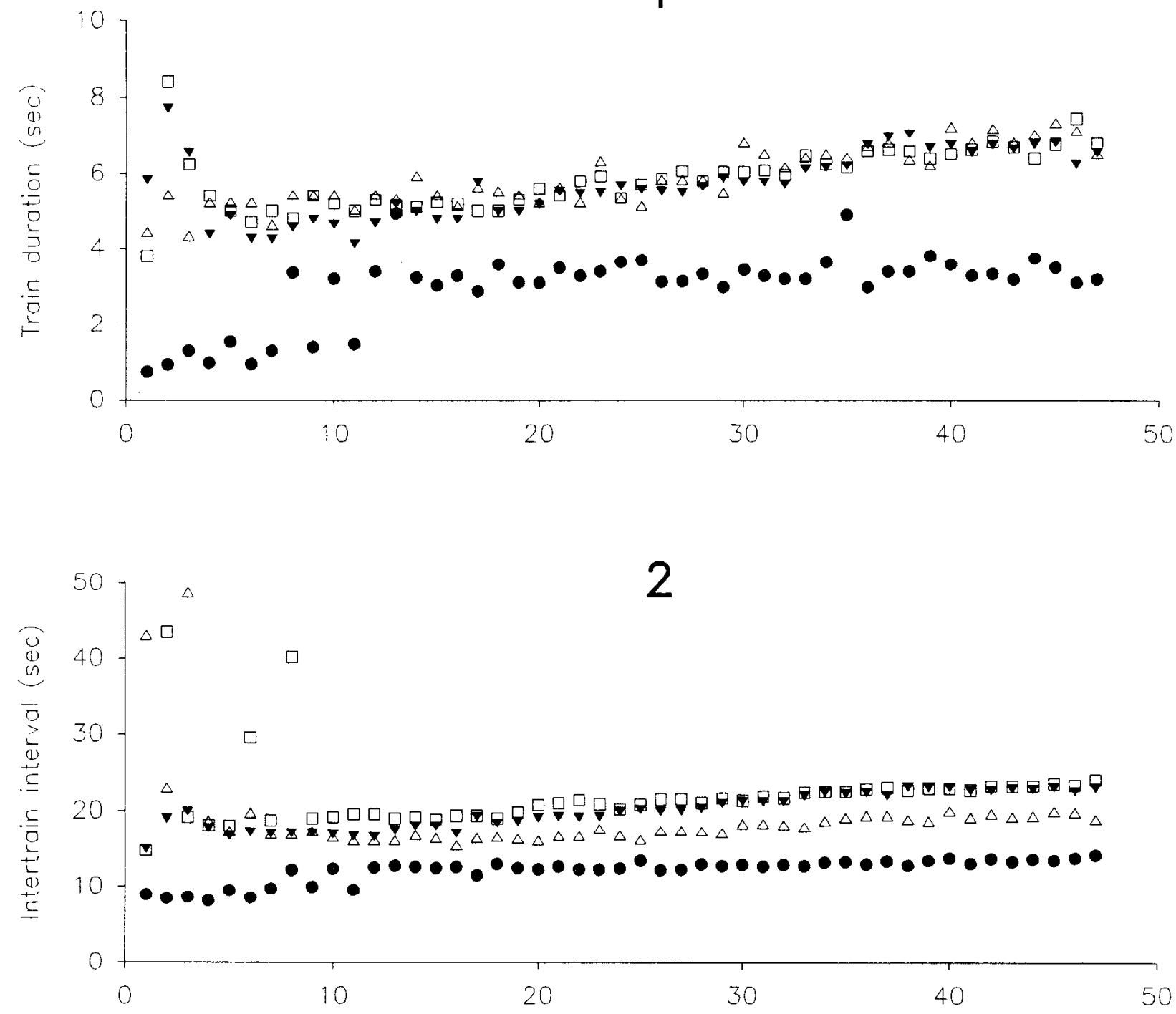

Successively numbered trains

B

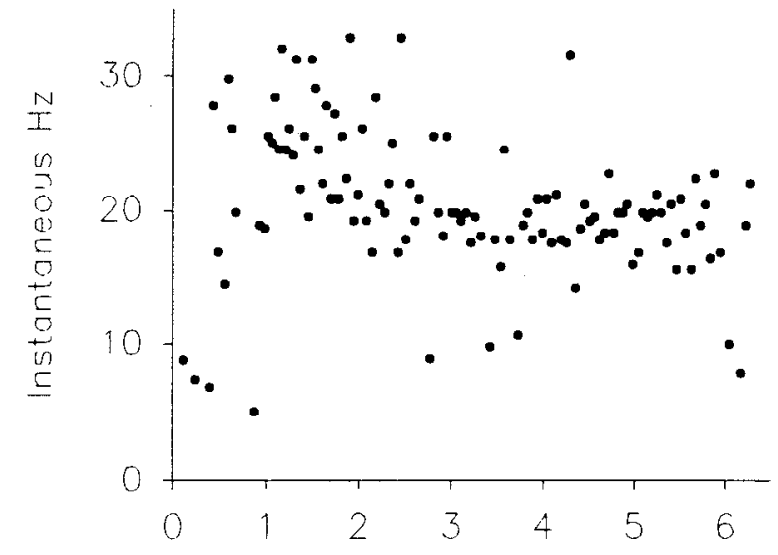

Time within single train (sec)

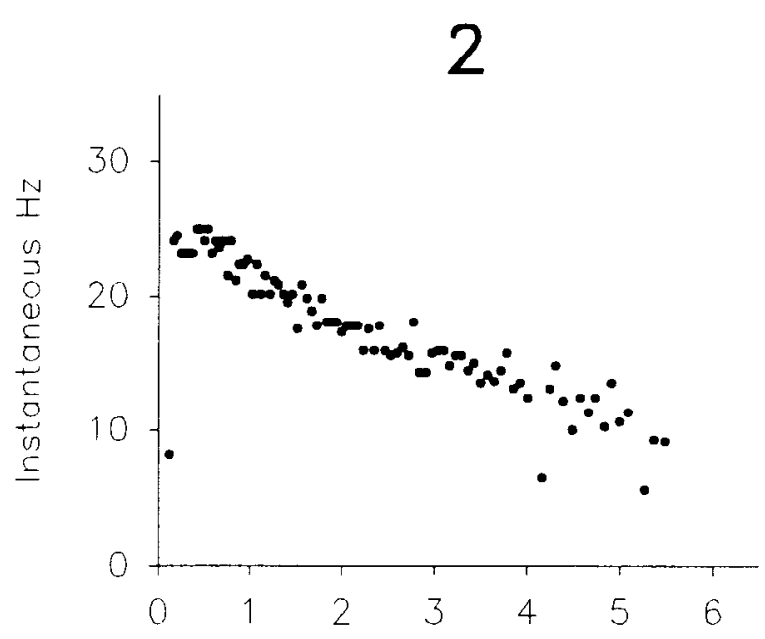

Time within single train (sec) 
A

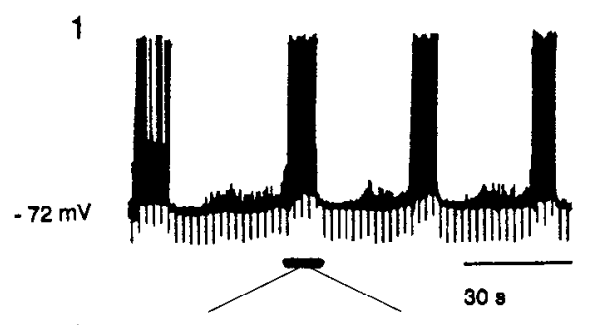

2

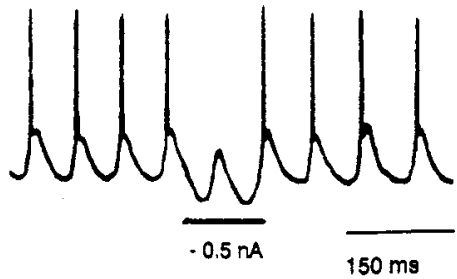

C

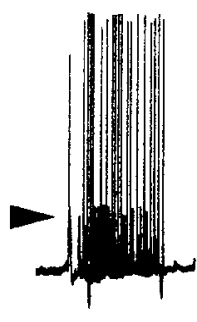

1

$-63 \mathrm{mV}(0.0 \mathrm{nA})$

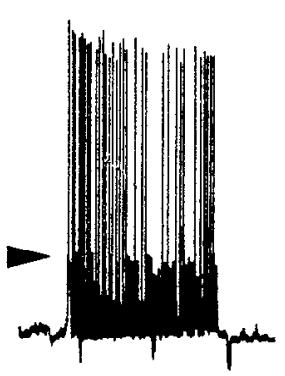

2
$-82(-0.9 n A)$
B

1

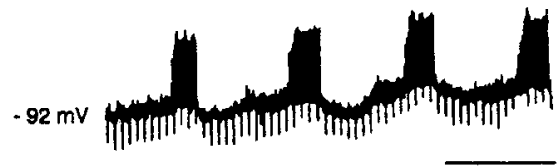

2
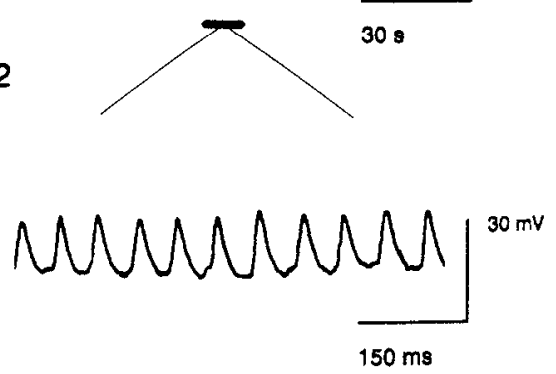

Figure 3. Effects of hyperpolarization on ACPD-induced oscillatory activity. Al, Stereotypical ACPD-induced oscillations. Downward deflections were the result of current injections $(0.5 \mathrm{nA}, 80 \mathrm{msec}, 0.5 \mathrm{~Hz})$. A2, Transient hyperpolarization (indicated by heavy bar) blocked a single action potential without influencing the rhythmicity of the ongoing depolarizations. $B$, Sustained hyperpolarization $(-1.3 \mathrm{nA})$ blocked action potentials without affecting rhythmicity. $C$, Incremental hyperpolarization (from $\mathrm{Cl}$ through $\mathrm{C4}$ ) progressively suppressed the occurrence of action potentials and augmented the amplitude of the underlying depolarizations. The arrows indicate the peak amplitude of the depolarizations.

ditionally, oscillations produced by tonic perfusion with ACPD ceased when $1 \mu \mathrm{M}$ TTX was added to the perfusion medium ( $n$ $=3$ slices).

\section{Effects of excitatory amino acid receptor antagonists on $A C P D$-induced oscillations}

The NMDA receptor antagonist CPP $(10-30 \mu \mathrm{M})$ did not block ACPD-induced oscillations in any of nine experiments $(n=5$ slices; Fig. 8A). This was true both when the antagonist was applied prior to exposure to ACPD, and when it was applied between and concomitantly with successive applications of ACPD. In contrast, the AMPA/kainate receptor antagonist CNQX (20-30 $\mu \mathrm{M})$ prevented the initiation of oscillatory activity by drop application of ACPD in nine experiments $(n=5$ slices; Fig. $8 B$ ). Additionally, when oscillatory activity was sustained by continuous bath perfusion of ACPD (100-200 $\mu \mathrm{M})$, addition of CNQX alone (10-20 $\mu \mathrm{M} ; n=3$ slices) to the perfusion media reversibly abolished the ACPD-induced oscillations.

Effects of metabotropic glutamate receptor antagonists on ACPD-induced oscillations

We used several of the recently developed phenylglycine derivatives to study the role of metabotropic glutamate receptors (mGluRs) in the production of the ACPD-induced oscillations. Bath application of ( + )-MCPG ( $1 \mathrm{~mm} ; n=5)$, a broad spectrum mGluR antagonist (Jane et al., 1993; Schoepp and Conn, 1993; Hayashi et al., 1994), reversibly blocked ongoing oscillations

Figure 2. Characterization of train duration, intertrain interval, and instantaneous frequency of depolarization. Four experiments are shown, with each of four symbols in $A I$ corresponding to the same experiment in $A 2 . A$, In response to ACPD ( $200 \mu \mathrm{M})$, the first several trains showed variable durations $(A I)$ and intertrain intervals $(A 2)$. Train durations and intertrain intervals became more uniform with repeated cycling. $B$, Instantaneous depolarization frequency (calculated from within-train interdepolarization intervals) was variable during the first few trains (B1). After repeated cycles of activity, the pattern of instantaneous depolarization became stereotypic. $B 2$, Instantaneous frequency (same cell as $B I$ ) reached a peak early within a given train, progressively slowed, then dropped to zero during the trough of the intertrain interval. 


\section{Intracellular and simultaneous field recording}

A

1

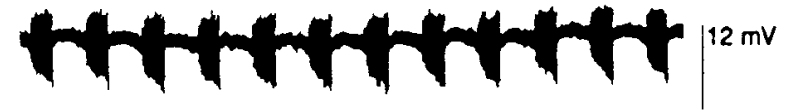

2
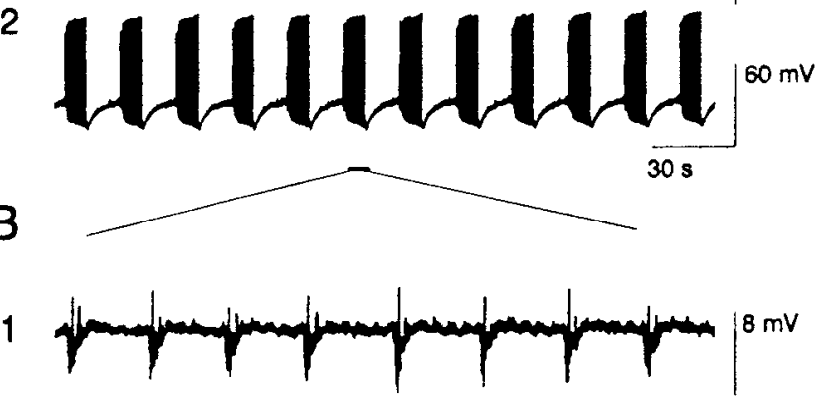

2

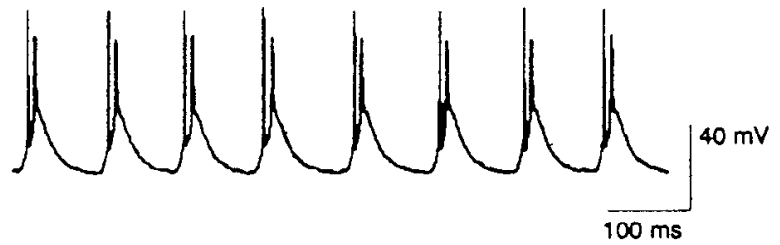

Figure 4. Paired field potential with pyramidal cell recordings show ACPD-induced activity is of a synchronous nature. Al, Rhythmic field potentials from hippocampal CA3 region were synchronous with intracellularly recorded activity (2), $B$, Expanded portion of the same recordings as shown in $A$.

produced by continuous perfusion of ACPD. (S)-4C3HPG (1 $\mathrm{mM} ; n=4)$ and $(S)-4 \mathrm{CPG}(500 \mu \mathrm{M}$ to $1 \mathrm{mM} ; n=5$; Fig. 9) similarly blucked ACPD-induced oscillations. The latter two phenylglycine derivatives are antagonists at mGluRs 1 and 5 , but have agonist activity at mGluRs 2 and 3 (Hayashi et al., 1994b). Another mGluR agonist, L-CCG-I, was ineffective at low concentrations (100-300 $\mu \mathrm{M})$, but initiated stereotypical oscillations at high concentrations ( $500 \mu \mathrm{M}$ to $2 \mathrm{mM}, n=4$, data not shown). Oscillations initiated by L-CCG-I were maintained even while titrating its concentration down to very low concentrations $(\approx 6 \mu \mathrm{M})$. L-CCG-I has been reported to be more potent than $\Lambda \mathrm{CPD}$ at mGluRs 1 and 5 , yet might preferentially activate mGluRs 2 and 3 at low doses (Watkins and Collingridge, 1994; Pin and Bockaert, 1995).

\section{Effects of GABA receptor antagonists on ACPD-induced oscillations}

Experiments were undertaken to determine if inhibition plays a significant role in producing or shaping ACPD-induced oscillatory activity, as it does with similarly appearing oscillations in the thalamus (von Krosigk et al., 1993). Sustained oscillations were first produced by bath perfusion of ACPD. Slices were then exposed to bicuculline (50 $\mu \mathrm{M} ; n=5)$ or picrotoxin $(50 \mu \mathrm{M} ; n$ $=3$ ), antagonists of $\mathrm{GABA}_{\mathrm{A}}$ receptor-mediated inhibition. Alternatively, to ensure effective suppression of $\mathrm{GABA}_{\mathrm{A}}$ receptormediated activily (evidenced by the appearance of epileptiform bursts), picrotoxin ( $n=6$ ) or bicuculline $(n=2)$ was perfused before exposure to ACPD. In neither set of experiments did $\mathrm{GABA}_{\mathrm{A}}$ antagonists block the oscillations (Fig. 10A). However, when ongoing oscillations were sustained by the continuous presence of ACPD, the addition of these antagonists to the perfusion medium increased the amplitude of the depolarizations

\section{Paired intracellular recordings}

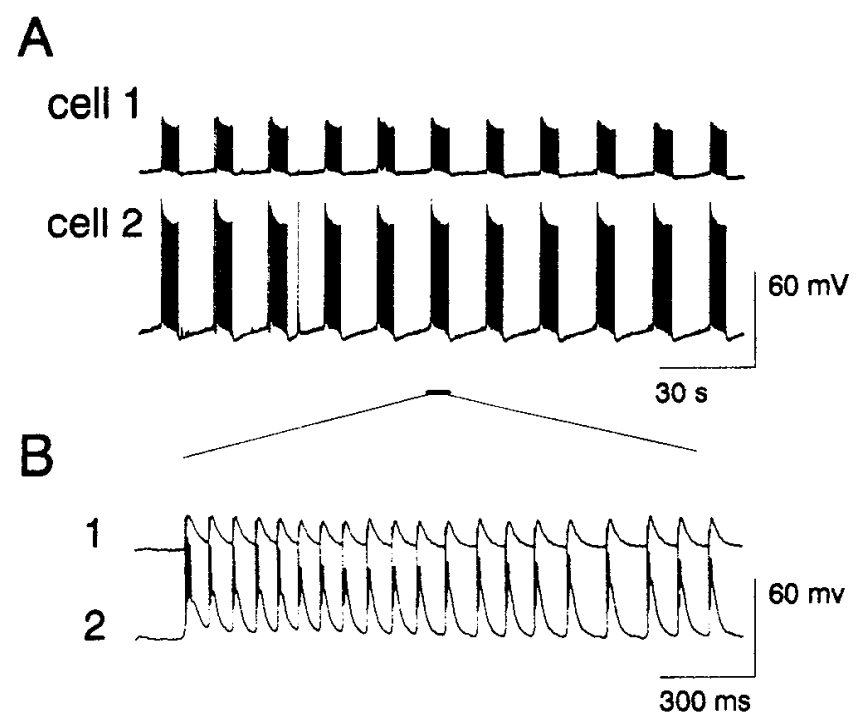

Figure 5. Dual intracellular pyramidal cell recordings from CA3 cells show ACPD-induced activity is highly synchronized. A, Cell 1 expressed ACPD-induced activity without action potentials. The trains of activity occurred synchronously with activity recorded from cell 2 . $B$, A portion of activity from the same cells as in $A$ at higher temporal resolution, revealing that the individual depolarizations within each train were highly synchronized.
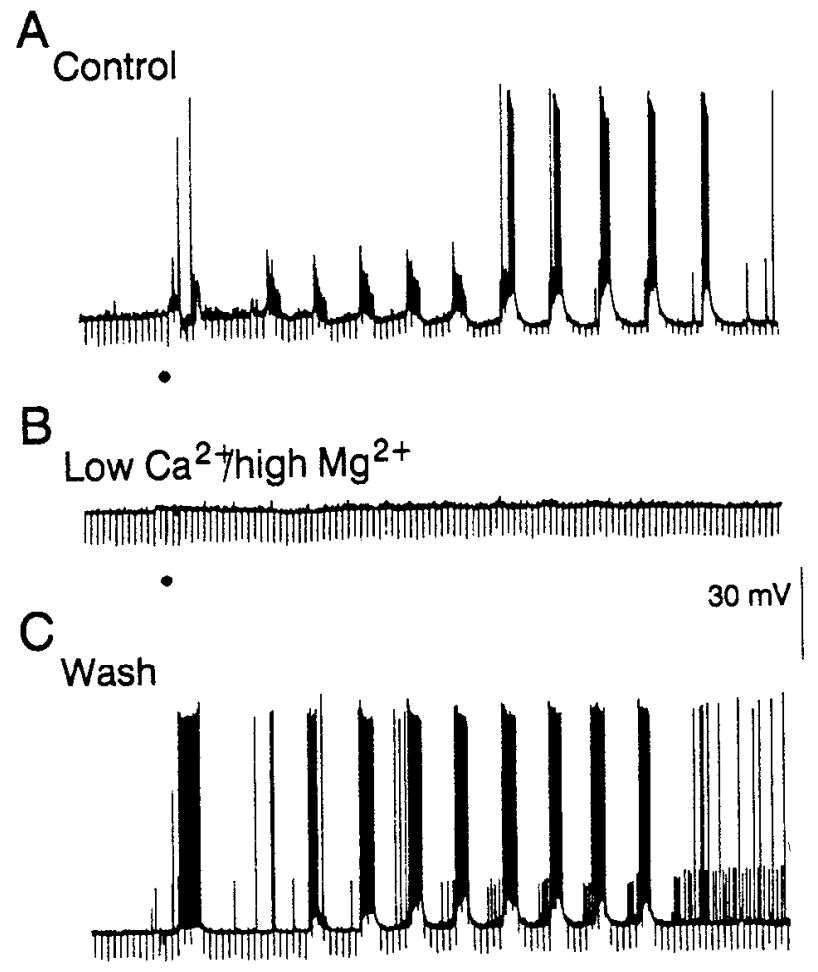

$30 \mathrm{~s}$

Figure 6. ACPD-induced activity is blocked by perfusion with low $\mathrm{Ca}^{2+} /$ high $\mathrm{Mg}^{2+}$ solution. A, Prior to manipulation of the perfusion media (control), drop application of ACPD ( $5 \mathrm{~mm}$, indicated by solid circles) produced oscillatory activity. $B$, Drop application of ACPD could not evoke oscillations in the same cell as in $A$ when the perfusion media contained low $\mathrm{Ca}^{2+} /$ high $\mathrm{Mg}^{2+} . C$, After reperfusion with control media, drop application of ACPD once again evoked oscillatory activity. 

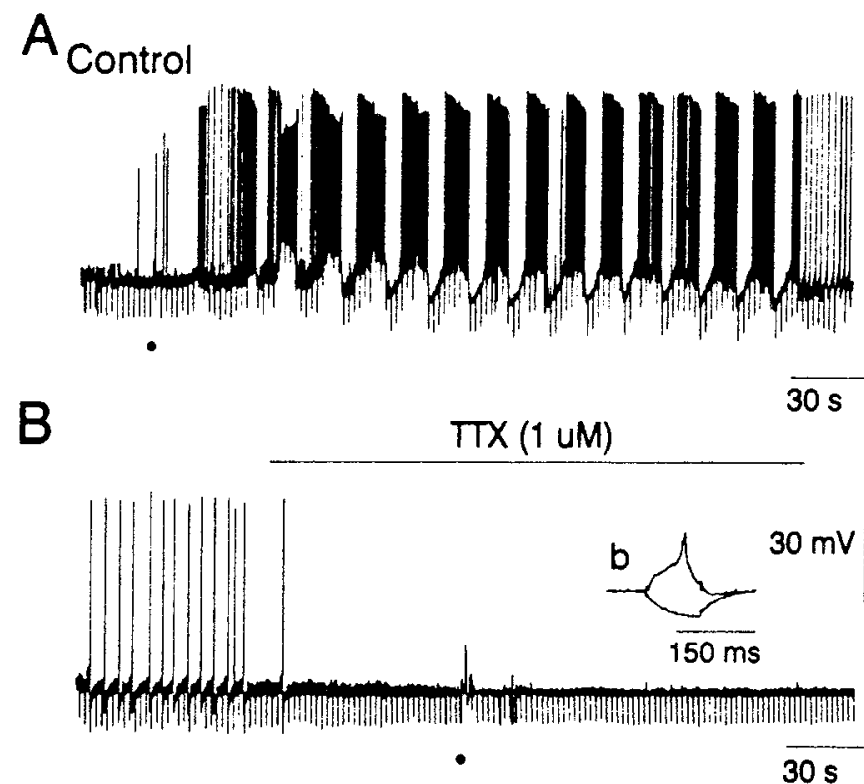

Figure 7. ACPD-induced activity is blocked by TTX. A, Drop application of ACPD ( $5 \mathrm{~mm}$, indicated by solid circles) produced stereotypic activity prior to manipulation of the perfusion media (control). $B$, Once TTX had blocked spontaneous activity, ACPD application did not evoke the oscillations. $b$, Current injection ( $80 \mathrm{msec}$ duration) produced a characteristic charging curve (hyperpolarizing) or calcium spikes (depolarizing), suggesting cell impalement was maintained.

within the trains, decreased the median frequency of the depolarizations within the trains from $15.3 \pm 1.0$ to $11.7 \pm 0.8 \mathrm{~Hz}$ (mean $\pm \mathrm{SEM} ; n=46$ trains; six slices; $P<0.03$ ), and decreased the quiescent period between trains from $20.42 \pm 2.83$ to $13.57 \pm 1.69 \mathrm{sec}$ (mean $\pm \mathrm{SEM} ; n=46$ quiescent periods; six slices; $P<0.04)$.

Similar experiments were carried out to assess the role of
$\mathrm{GABA}_{B}$ receptor-mediated inhibition in the generation of ACPD-induced oscillations. After stable oscillations were elicited by $A C P D$ in the presence of $\mathrm{GABA}_{\mathrm{A}}$ receptor antagonists, addition of the $\mathrm{GABA}_{\mathrm{B}}$ receptor antagonist CGP $35348(500 \mu \mathrm{M}$ to $1 \mathrm{mM}$ ) did not have an obvious effect on the oscillations ( $n$ $=8$; Fig. $10 B$ ). In the absence of $\mathrm{GABA}_{\mathrm{A}}$ receptor antagonists, application of CGP 35348 either alone $(n=3)$ or in combination with 2-hydroxysaclofen (another $\mathrm{GABA}_{\mathrm{B}}$ receptor antagonist; 1 $\mathrm{mM} ; n=2$ ) also was without an obvious effect on ongoing ACPD-induced oscillations.

\section{Effects of $A C P D$ in the presence of $G A B A_{A}$ antagonists}

Before ACPD was introduced, picrotoxin or bicuculline $(50 \mu \mathrm{M}$ each) elicited spontaneous epileptiform bursts of 120-800 msec duration that recurred regularly every $6-16 \mathrm{sec}(n=8$ slices; Fig. 11A). The interval between these spontaneous bursts gradually decreased to less than $500 \mathrm{msec}$ as the concentration of ACPD was gradually increased (Fig. $11 B$ ). The duration of these bursts became abbreviated to $50-100 \mathrm{msec}$ when the concentration of ACPD was greater than $50 \mu \mathrm{M}$ ( $n=8$ slices). These effects of ACPD on epileptiform bursts produced by $\mathrm{GABA}_{\mathrm{A}}$ receptor antagonists are consistent with the findings of Burke and Hablitz (1995) as well as with recent studies performed in this laboratory which focused on the role of mGluR subtypes 2 and 3 in accelerating the rate of these brief duration epileptiform bursts at low concentrations of mGluR agonists (Merlin et al., 1995). Other investigators have reported that acceleration or suppression of epileptiform bursting can be achieved by varying the concentration of ACPD (Sheardown, 1992; Taschenberger et al., 1992; Burke and Hablitz, 1995).

Effects of tetanic stimulation in the presence of $G A B A_{A}$ antagonists and $A C P D$

Experiments were carried out in the presence of $\mathrm{GABA}_{A}$ antagonists to test the effect of tetanic stimulation while elevating the concentration of ACPD. Tetanic stimulation (4-8 pulses, 50

A

Control

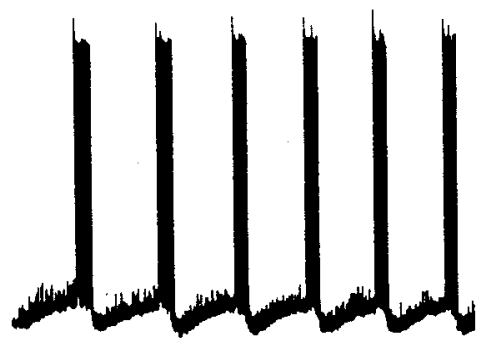

B

Control

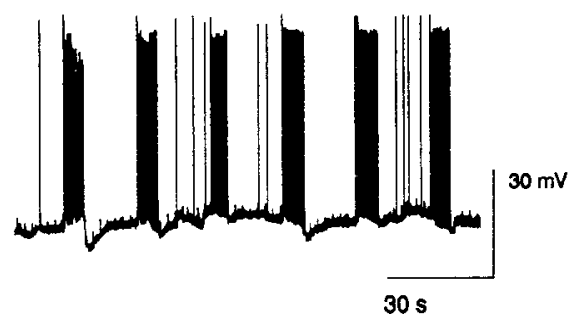

CNOX (20 uM)

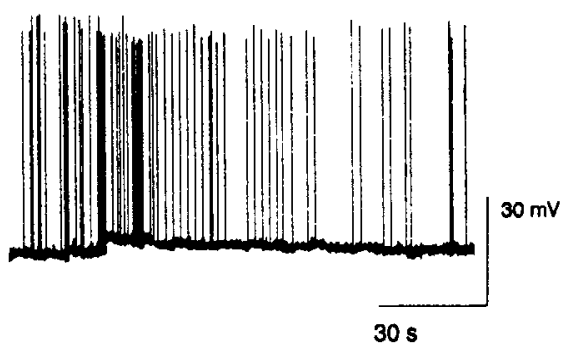

Figure 8. Fiffects of ionotropic glutamate receptor antagonists on ACPDinduced oscillatory activity. $A$, After $\Lambda C P D$ induced activity was reliably evoked by drop application (control), the NMDA receptor antagonist CPP was then bath applied for at least 20 min prior to and concomitantly with additional drop applications of ACPD. Inhibition of NMDA receptors with CPP did not block the oscillations. $B$, Blockade of AMPA/kainate receptors with CNQX blocked ACPD-induced oscillatory activity. 


\section{A control}

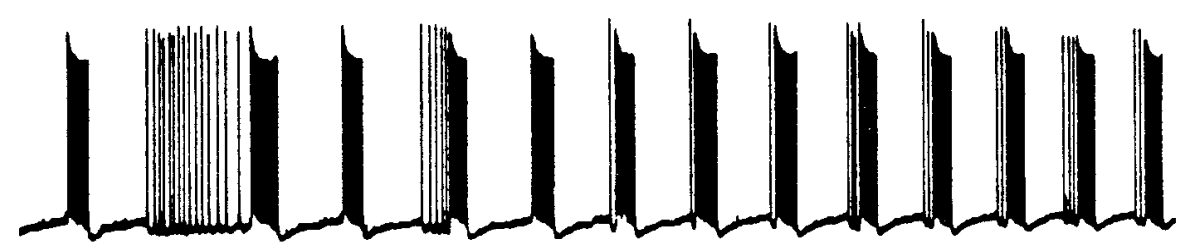

B

(S)-4C.PG (1 mM)

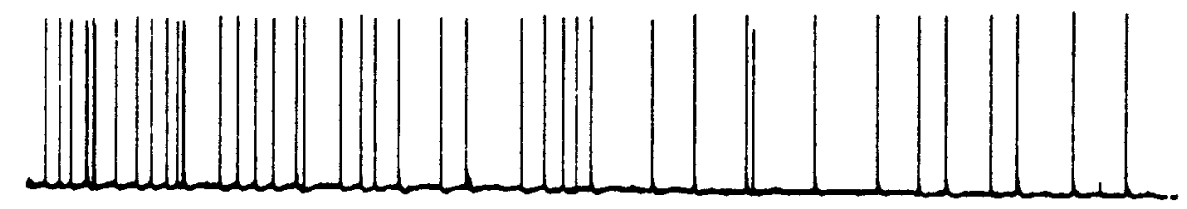

C

Wash

Figure 9. (S)-4CPG blocks ACPD-induced oscillatory activity. $A$, Continuous perfusion with $200 \mu \mathrm{M}$ ACPD produced stereotypical oscillatory activity (control). B, ACPD-induced activity was blocked after a few minutes exposure to $(S)-4 C P G$, an antagonist at mGluRs 1 and 5. C, Oscillatory activity resumed after $(S)-4 C P G$ was washed out from the perfusion medium.

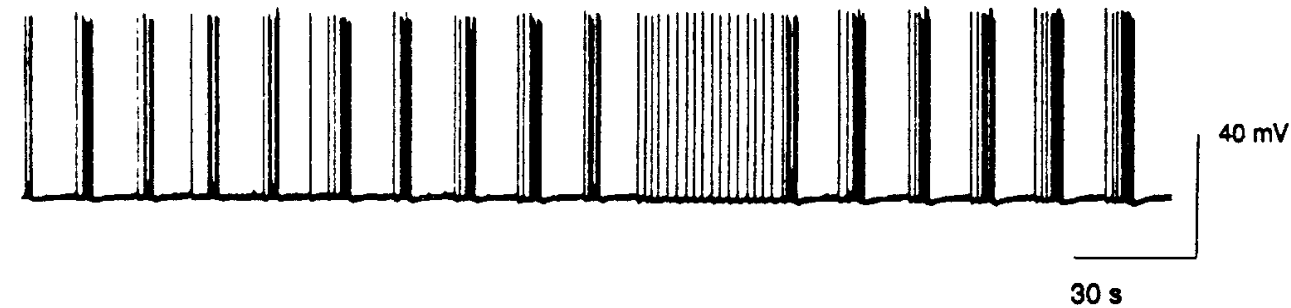

$\mu$ sec pulses, $20-60 \mathrm{~Hz}$ ) of afferent fibers in the presence of $\mathrm{GABA}_{\mathrm{A}}$ antagonists alone evoked epileptiform bursts that were indistinguishable from those occurring spontaneously (Fig. 11A). At less than $20 \mu \mathrm{M}$ ACPD, tetanic stimulation of afferent pathways failed to produce trains of oscillatory activity in each of 44 trials ( $n=4$ slices). At $20-35 \mu \mathrm{M}$ ACPD, tetanization evoked more prolonged discharges that resembled trains in response to 12 of 35 tetanizations (Fig. $11 B ; n-4$ slices). $\Lambda t$ t0-60 $\mu \mathrm{M}$ ACPD, tetanization produced train-like discharges in response to 19 of 21 tetanizations ( $n=4$ slices). The minimum ("threshold") concentration of ACPD required to elicit spontaneous trains of oscillatory activity, with or without GABA $_{A}$ antagonists, was $20-70 \mu \mathrm{M}$ ( $n=12$ slices). Tetanization just prior to an expected train, at higher concentrations of ACPD, produced evoked trains that were indistinguishable from spontaneous trains (Fig. 11C).

In other experiments, the concentration of ACPD was initially increased to $50 \mu \mathrm{M}$ ( $n=3$ slices). This concentration was usually just below threshold for the generation of spontaneous ACPD-induced oscillatory activity. Tetanization of slices under these conditions produced an initial train which could occur in isolation (Fig. 12) or could be followed by up to six spontaneous trains of stereotypical ACPD-induced oscillatory activity (not shown). Infrequently occurring trains (spontaneous or evoked) tended to be very prolonged (compare Figs. 11, 12).

Since tetanization produced a transient period (one to six trains) of ACPD-like oscillations in the presence of subthreshold concentrations of ACPD, the stimulation likely induced the oscillations by increasing the amount of mGluk activation by the glutamate that was released. Trains of ACPD-like oscillations did not occur in response to tetanization in the presence of MCPG or $(S)-4 \mathrm{CPG}$.

\section{Discussion}

\section{General findings}

This article describes a novel form of oscillatory activity that is initiated when the level of $\mathrm{mGluR}$ activation is relatively high (generally $>60 \mu \mathrm{M}$ ACPD). This ACPD-induced uscillatory activity consists of rhythmic $(\approx 0.04 \mathrm{~Hz}$ ) trains of depolarizations $(3-38 \mathrm{~Hz})$ which are synchronously generated in neighboring neurons (Figs. 4, 5). The oscillations primarily result from excitatory interactions (Figs. 8, 9), presumably involving recurrent excitatory synapses. GABA receptor-mediated inhibitory interactions play a modulatory role in determining the frequency of the oscillations.

Several lines of evidence suggest that the synchronized de- 
A

$1 \mathrm{a}$

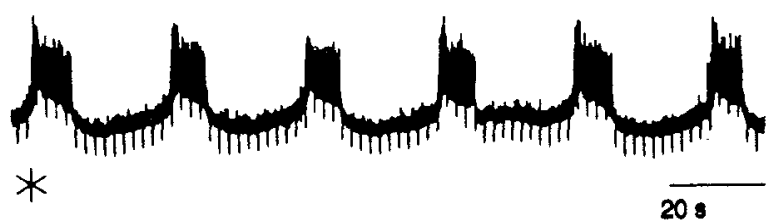

$1 b$

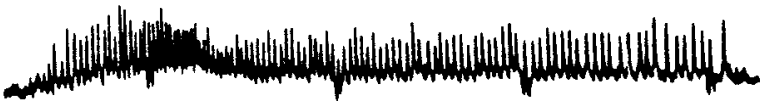

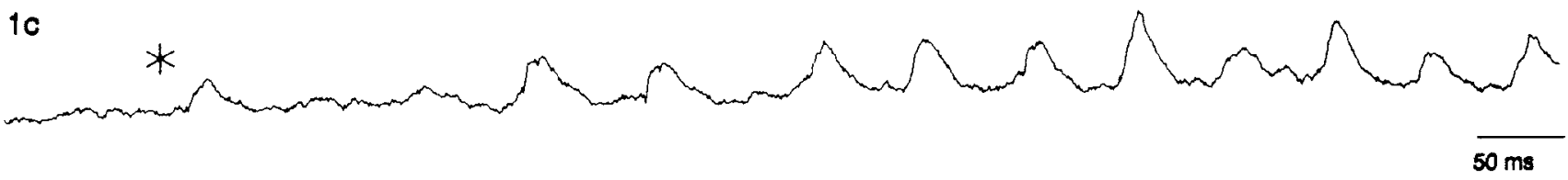

bicuculline

$2 a$

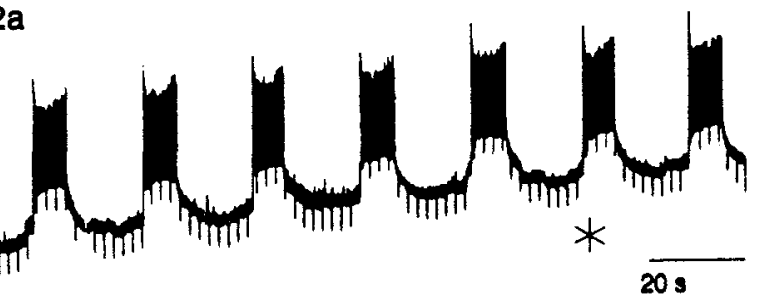

$2 b$

$35 \mathrm{mv}$

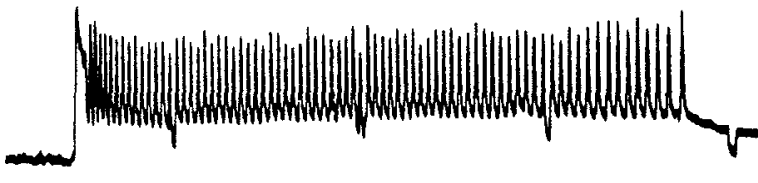

18

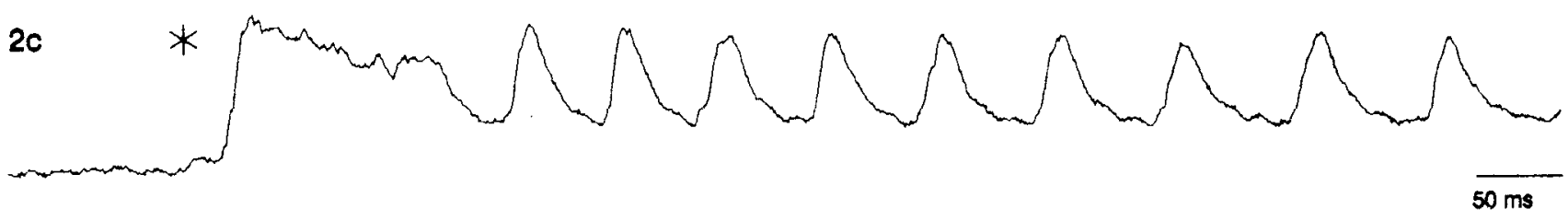

B

bicuculline

$1 \mathrm{a}$

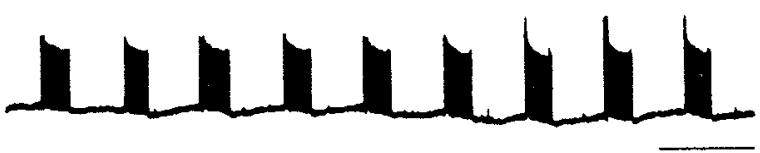

209

\section{bicuculline and CGP 35348}

$2 a$

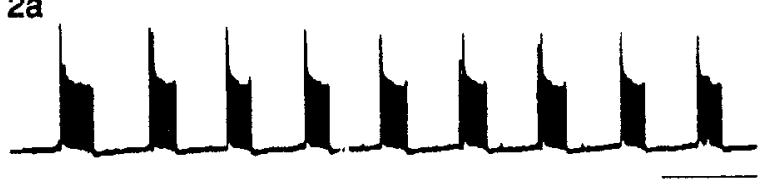

$20 \mathrm{~s}$
$1 b$

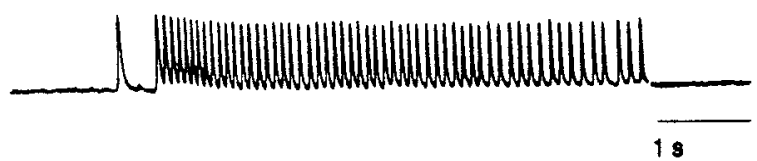

$25 \mathrm{mV}$

Figure 10. Blockade of GABAergic inhibition does not block ACPD-induced oscillatory activity. Ala, Oscillatory activity was produced by tonic perfusion with ACPD $(200 \mu \mathrm{M})$. A $1 b, \Lambda$ single train of activity from the same cell as in Ala. AIc, Asterisk indicates a portion of activity from the first train in Ala. A2a, Addition of bicuculline to the perfusion media augmented the amplitude of the oscillatory activity. $B$, In experiments where ACPD and bicuculline and were perfused together $(B l a, B I b)$, the addition of the GABA $A_{\mathrm{B}}$ antagonist CGP35348 $(1 \mathrm{mM}, B 2 a, B 2 b)$ for at least an hour did not block the oscillations. 


\section{Evoked}

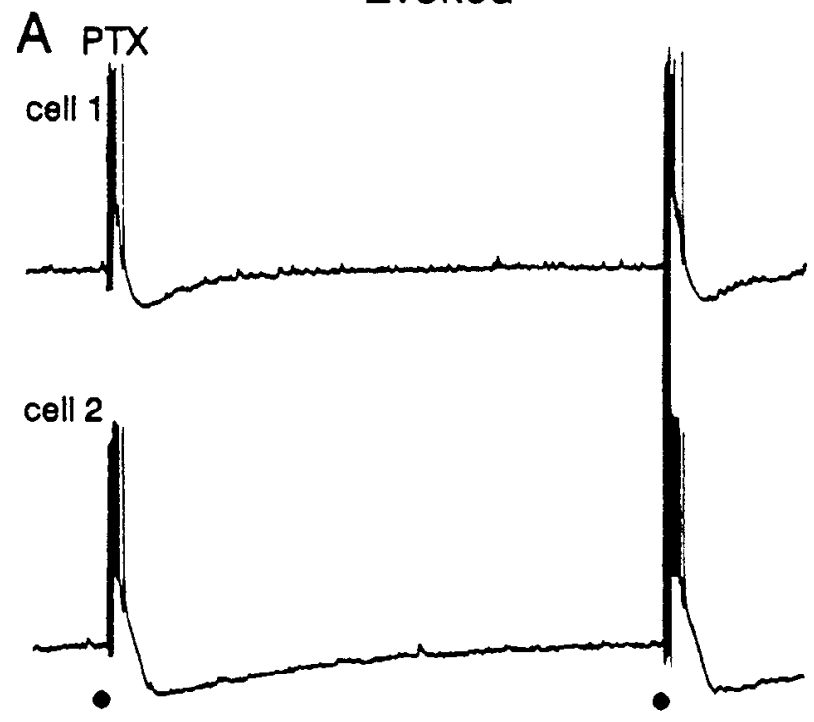

\section{B PTX + low [ACPD]}

\section{cell 1}
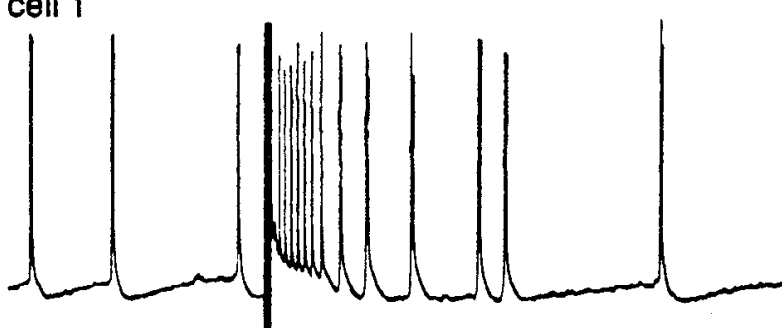

cell 2
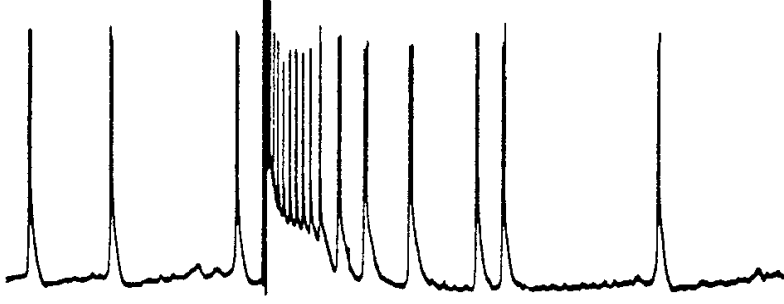

\section{PTX + high [ACPD]}

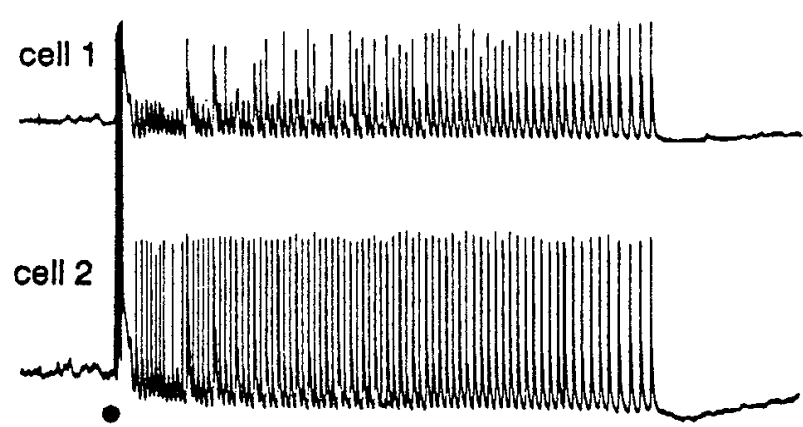

Spontaneous
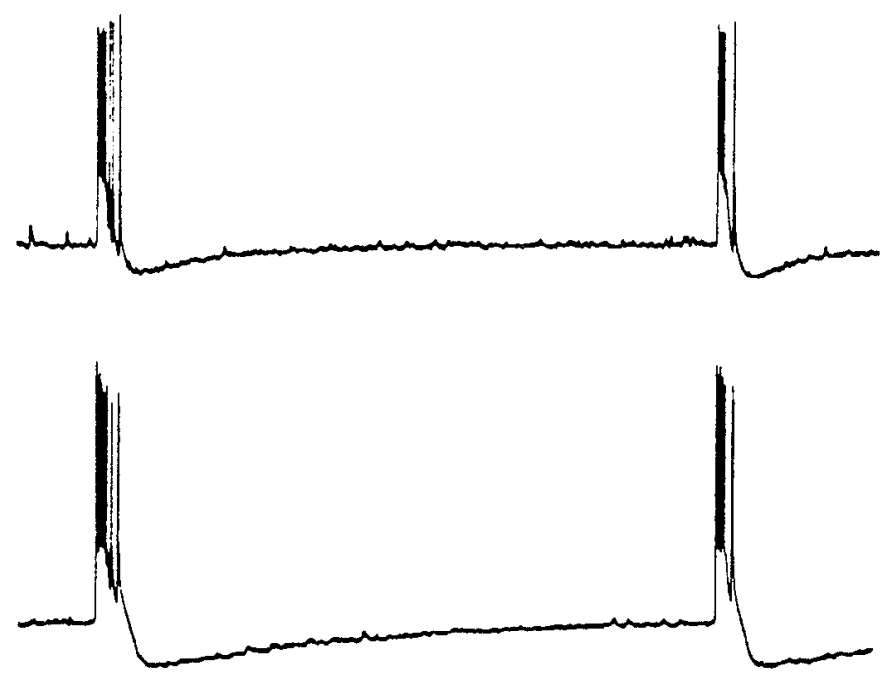
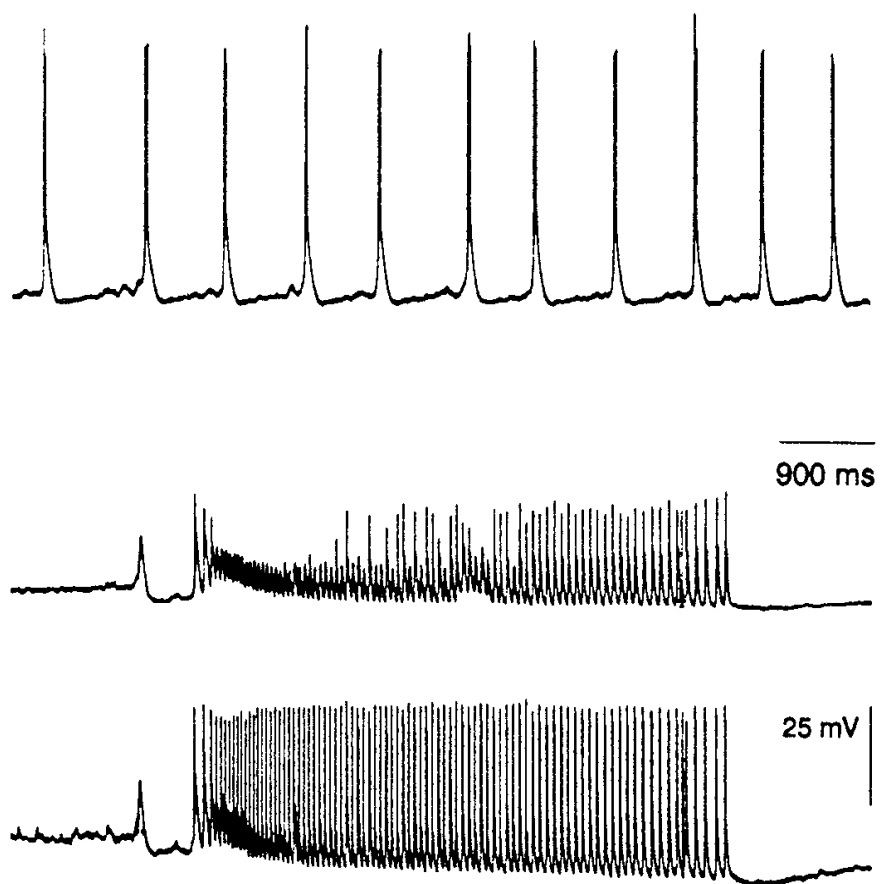

Figure 11. This figure shows paired intracellular recordings from CA3 neurons to compare evoked (tetani indicated by solid circles) and spontaneous activity in the presence of picrotoxin (PTX, $50 \mu \mathrm{M}$ ) while the concentration of ACPD was increased. A, In the presence of PTX alone, evoked bursts resembled spontaneous bursts. $B$, In the presence of $30 \mu \mathrm{M}$ ACPD, spontaneous bursts occurred at an accelerated rate and were abbreviated in duration (see text). Accelerated bursting can be seen to the left of the tetanus and in the right half of $B$. Tetanic stimulation evoked a more prolonged synchronized discharge at this concentration of ACPD. $C$, At high concentrations of ACPD (100 $\mu \mathrm{M})$, evoked trains resembled spontaneous trains. 


\section{PTX + subthreshold [ACPD]}

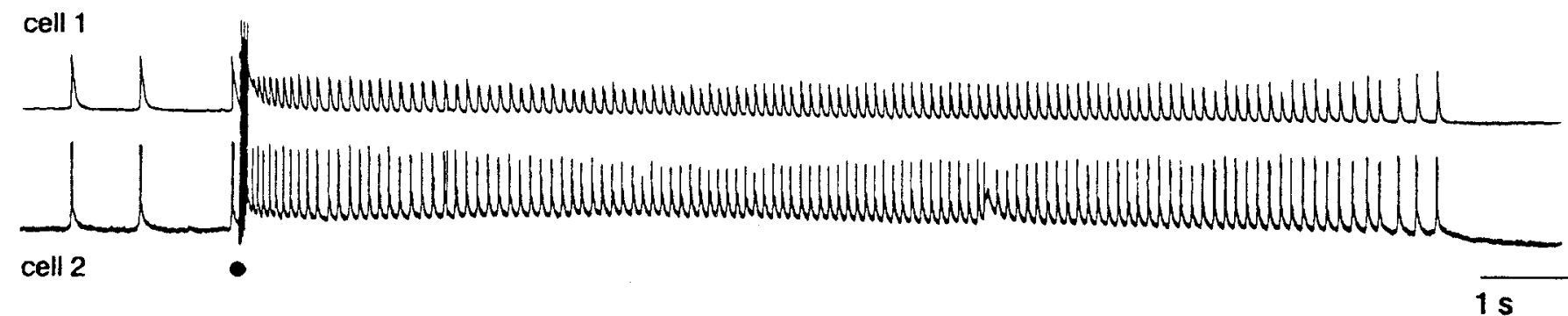

Figure 12. Extracellular stimulation evoked trains similar to ACPD-induced activity when the ACPD concentration was subthreshold for the generation of spontaneous trains. This figure shows paired intracellular recordings from CA3 neurons from a slice initially treated with picrotoxin (PTX, $50 \mu \mathrm{M}$ ). Three accelerated epileptiform bursts can be seen to the left of the tetanus (tetanus indicated by solid circle). ACPD (50 $\mu \mathrm{M}$ ) was not sufficient to induce spontaneous trains of oscillatory activity in this preparation, yet tetanic stimulation at this concentration evoked a train. Single trains had the characteristics of prolonged ictal-like discharges.

polarizations within each train represent synaptically generated potentials. Firstly, the depolarizations within each train increase in amplitude in response to hyperpolarizing current (Fig. 3), a finding characteristic of chemical synaptic transmission (Hub bard et al., 1969). Secondly, the depolarizations are absent when slices are perfused with a low $\mathrm{Ca}^{2+} /$ high $\mathrm{Mg}^{2+}$ medium (Fig. 6), or when sodium-dependent action potentials are blocked by TTX (Fig. 7). This suggests that the oscillations are not simply an intrinsic membrane oscillation. Thirdly, the activity is blocked by the AMPA/kainate receptor antagonist CNQX (Fig. 8), suggesting that AMPA/kainate receptors mediate an essential synaptic component required to couple the CA3 neurons.

\section{Pharmacological properties of the ACPD-induced oscillations}

Although AMPA/kainate receptor-mediated synaptic transmission is required for generating the synchronized depolarizations that constituted ACPD-induced oscillations, this activity did not occur unless metabotropic agonists were present. The activation of mGluRs appears to be essential to condition the network to generate ACPD-induced oscillations. Since ACPD is an agonist at most mGluR subtypes (Tanabe et al., 1992; Schoepp and Conn, 1993; Chung et al., 1994), the oscillations produced by ACPD could be mediated by PI-coupled mGluRs (mGluRs 1 and 5), and/or by mGluRs negatively coupled to cyclic AMP (mGluks 2 and 3). There is no evidence as of yet regarding the exact role of the above second messenger systems in generating the ACPD-induced oscillatory activity reported in this article.

The effectiveness of the broad spectrum mGluR antagonist (+)-MCPG in blocking ACPD-induced oscillatory activity strongly suggests a role for mGluRs in the production of the oscillations (Chinestra et al., 1993; Jane et al., 1993; Hayashi et al., 1994b). The antagonist actions of (S)-4C3HPG and (S)4CPG on the oscillations suggest that PI-coupled mGluRs are required to generate the oscillations because both of these agents are antagonists at mGluRs 1 and 5, but agonists at mGluRs 2 and 3 (Birse et al., 1993; Eaton et al., 1993; Jones et al., 1993; Hayashi et al., 1994b). The high concentration of ACPD necessary to generate these oscillations also is consistent with the involvement of mGluRs 1 or 5 because molecular and biochemical experiments with cortical tissue suggest that higher levels of glutamate or ACPD are required for activation of mGluRs 1 and 5 than for activation of mGluRs 2 and 3 (Abe et al., 1992; Schoepp et al., 1992; Tanabe et al., 1992; Cartmell et al., 1993a,b, 1994; Challis et al., 1994). Additionally, the concen- tration of ACPD required to modulate the rate of interictal bursting through activating mGluRs 2 and/or 3 (Merlin et al., 1995) is significantly lower than that required to initiate the prolonged discharges reported herein. While the above discussion strongly suggests a role for PI-coupled mGluRs, this certainly does not rule out a role for other mGluRs. One role for other subtypes could be that their activation may reduce inhibition to a level that would permit synchronization. The role of mGluRs 2 and 3 in reducing inhibition has been studied in detail by Poncer et al. (1995).

How do ACPD-induced oscillations compare with other similarly appearing oscillations?

The oscillatory activity reported in this article is a new finding and may be related to other similarly appearing oscillations which have been studied in some detail. Two distinct features of the ACPD-induced oscillations are the following. (1) Each train consists of synchronized repetitive depolarizations at frequencies up to $38 \mathrm{~Hz}$. (2) The trains of depolarizations recur every $10-50 \mathrm{sec}$, separated by quiescent periods. Similarly, thalamocortical spindle oscillations (Steriade et al., 1985, 1990, 1993c; Buzsáki et al., 1988; von Krosigk et al., 1993), hippocampal rhythmic slow activity in vitro, ("RSA"; Bland, 1986; MacVicar and Tse, 1989), and slow neocortical oscillations (Steriade et al., 1993a) all consist of periodic clusters of depolarizations. Do ACPD-induced oscillations require the same set of synaptic components as any of the above oscillations?

Experiments in vitro have demonstrated that thalamic spindle oscillations (von Krosigk et al., 1993) and hippocampal RSA (MacVicar and Tse, 1989; Traub et al., 1992) both are sensitive to AMPA/kainate receptor antagonists, as are the ACPD-induced oscillations reported in this article. Slow neocortical oscillations, on the other hand, are suggested to be modulated by NMDA Ieceptor mediated activity (Steriade et al., 1993a). Thalamic spindle oscillations are distinctive in that they are blocked by the combined application of antagonists for $\mathrm{GABA}_{\mathrm{A}}$ and $\mathrm{GABA}_{\mathrm{B}}$ receptor-mediated inhibition (von Krosigk et al., 1993). In contrast, antagonists of GABA receptor-mediated inhibition have no effect on in vitro RSA (MacVicar and Tse, 1989; Traub et al., 1992) and do not block the ACPD-induced oscillatory activity reported in this article.

The intertrain interval. Steriade et al. (1993a) suggest that synaptic inhibition mediated by a chloride conductance contributes to determining the length of the quiescent period between 
trains of the slow neocortical rhythm. In our studies, GABA receptor antagonists decreased the duration of the quiescent period between trains from 20 to $14 \mathrm{sec}$. This finding is consistent with a modulatory role for $\mathrm{GABA}_{\mathrm{A}}$ receptors in shaping $\mathrm{ACPD}$ induced oscillations, and distinguishes this activity from carbachol-induced RSA recorded in vitro which is unaffected by GABA antagonists (MacVicar and Tse, 1989). A role for fast inhibition is not surprising because $\mathrm{GABA}_{\mathrm{A}}$ receptor-mediated inhibition develops rapidly enough to influence the process of synchronization (Traub et al., 1987; Wong and Miles, 1993).

At present, the exact ionic basis for slow rhythms is unknown. With regard to thalamic spindling, the oscillations depend on rebound bursting involving a low threshold calcium conductance $\left(I_{T}\right)$, while train termination involves interactions between $I_{T}$ and the depolarizing influence of $I_{h}$ (McCormick and Pape, 1990; Soltesz et al., 1991; Huguenard and McCormick, 1992; McCormick and von Krosigk, 1992). In contrast, ACPD-induced oscillations do not appear to involve rebound bursting, and the termination of each train is accompanied by a hyperpolarization (Alger and Williamson, 1988) followed by a slow depolarization that is reminiscent of a pace-making current (Leresche et al., 1990; DiFrancesco, 1991; Huguenard and McCormick, 1992).

Intratrain depolarizations. Our experiments with ACPD-induced oscillations demonstrate a predominant role for glutamate receptor-mediated conductances (Jonas and Spruston, 1994; Westbrook, 1994) in the CA3 region. ACPD-induced oscillations were present in CA3 "mini slices" but absent in CA1 "mini slices" (data not shown). This is consistent with the known function of CA3 recurrent synapses (Miles and Wong, 1986; Ishizuka et al., 1990) which generate synchronized discharges in the hippocampal slice (Traub and Wong, 1982; Wong and Traub, 1983; Traub and Miles, 1991; Bianchi and Wong, 1994).

$G A B A_{A}$ receptor antagonists had the dual effect of enhancing the amplitude of the depolarizations while decreasing the median frequency of depolarization from 15.3 to $11.7 \mathrm{~Hz}$. This was particularly true when the depolarizations were of low amplitude and the trains recurred infrequently. These findings are consistent with a role for $\mathrm{GABA}_{\mathrm{A}}$ receptors in modulating $\mathrm{ACPD}$ induced oscillations. The results also suggest that inhibition was not completely blocked when ACPD-induced oscillatory activity occurred. The modulatory role of residual inhibition in shaping ACPD-induced oscillations resembles the findings of von Krosigk et al. (1993) who report that thalamic spindles are also augmented and slowed by $\mathrm{GABA}_{\mathrm{A}}$ antagonists. However, in contrast to the generation of thalamic spindle oscillations which require excitatory-inhibitory interactions (Jahnsen and Llinás, 1984a,b; Steriade et al., 1985; Buzsáki ct al., 1988; von Krosigk et al., 1993; Wang and Rinzel, 1993; Bal et al., 1995a,b), generation of ACPD-induced oscillations appear to require excitatory-excitatory interactions and are only modulated by residual tonic or phasic inhibition.

\section{General conclusions}

Clusters of synchronized depolarizations are a fundamental manifestation of interactions in neural circuitry and can be expressed during physiological or pathophysiological events. Different circuitries can generate similar patterns of activity yet possess different synaptic and intrinsic mechanisms. The present study suggests that ACPD-induced oscillations, slow neocortical rhythms (Steriade, 1993a-c), spindle waves (von Krosigk et al., 1993), and carbachol-induced RSA (MacVicar and Tse, 1989) result from distinct yet overlapping mechanisms. Our findings pro- duced in vitro in the continuous presence of mGluR activation are probably most relevant to the pathophysiology of epileptiform discharges (Miles et al., 1984; Swann et al., 1986, 1993; Traub et al., 1991). During the course of pathophysiological brain activity, mGluR activation could transiently reach a level such that an ictal discharge similar to the trains of depolarizations reported here might occur. The results we have presented may lead to an understanding of the mechanisms underlying the transition from interictal to ictal discharge.

\section{References}

Abe T, Sugihara H, Nawa $H$, Shigemoto R, Mizuno N, Nakanishi S (1992) Molecular characterization of a novel metabotropic glutamate receptor mGluR5 coupled to inositol phosphate/Ca ${ }^{2+}$ signal transduction. J Biol Chem 267:13361-13368.

Akazawa C, Ohishi H, Nakajima Y, Okamoto N, Shigemoto R, Nakanishi S, Mizuno N (1994) Expression of mRNAs of L-AP4-sensitive metabotropic glutamate receptors (mGluR4, mGluR6, mGluR7) in the rat retina. Neurosci Lett 171:52-54.

Alger BE, Williamson A (1988) A transient calcium-dependent potassium component of the epileptiform burst after-hyperpolarization in rat hippocampus. J Physiol (Lond) 399:191-205.

Bal T, von Krosigk M, McCormick DA (1995a) Synaptic and membrane mechanisms underlying synchronized oscillations in the ferret lateral geniculate nucleus in vitro. J Physiol (Lond) 483:641-663.

Bal T, von Krosigk M, McCormick DA (1995b) Role of the ferret perigeniculate nucleus in the generation of synchronized oscillations in vitro. J Physiol (Lond) 483:665-685.

Baskys A, Malenka RC (1991) Agonists at metabotropic glutamate receptors presynaptically inhibit EPSCs in neonatal rat hippocampus. J Physiol (Lond) 444:687-701.

Baude A, Nusser Z, Roberts JD, Mulvihill F, Mcllhinney RA, Somogyi P (1993) The metabotropic glutamate receptor (mGluR1) is concentrated at perisynaptic membrane of neuronal subpopulations as detected by immunogold reaction. Neuron 11:771 787.

Bianchi R, Wong RKS (1994) Carbachol-induced synchronized rhythmic bursts in $\mathrm{CA} 3$ neurons of guinea pig hippocampus in vitro. $J$ Neurophysiol 72:131-138.

Birse EF, Eaton SA, Jane DE, Jones PL, Porter RHP, Pook PC-K, Sunter DC, Udvarhelyi PM, Wharton B, Roberts PJ, Salt TE, Watkins JC (1993) Phenylglycine derivatives as new pharmacological tools for investigating the role of metabotropic glutamate receptors in the central nervous system. Neuroscience 52:481-488.

Bland BH (1986) The physiology and pharmacology of hippocampal formation theta rhythms. Prog Neurobiol 26:1-54.

Bolshakov VY, Siegelhaum SA (1994) Postsynaptic induction and presynaptic expression of hippocampal long-term depression. Science 264:1148-1152.

Bortolotto Z^, Bashir ZI, Davies CH, Collingridge GL (1994) A molecular switch activated by metabotropic glutamate receptors regulates induction of long-term potentiation. Nature 368:740-743.

Burke JP, Habliz JJ (1995) Modulation of epileptiform activity by metabotropic glutamate receptors in immature rat neocortex. J Neurophysiol 73:205-217.

Buzsáki G, Bickford RG, Ponomareff G, 'l hal LJ, Mandel R, Gage FH (1988) Nucleus basalis and thalamic control of neocortical activity in the freely moving rat. J Neurosci 8:4007-4026.

Cartmell J, Alistair RC, Kemp JA, Kendall DA, Alexander SPH (1993a) Subtypes of metabotropic excitatory amino acid receptor distinguished by stereoisomers of the rigid glutamate analogue, 1-aminocyclopentane-1,3-dicarboxylate. Neurosci Lett 153:107-110.

Cartmell J, Kemp JA, Alexander SPH, Kendall DA (1993b) Endogenous adenosine regulates the apparent efficacy of 1-aminocyclopentyl-1S,3R-dicarboxylate inhibition of forskolin-stimulated cyclic AMP accumulation in rat cerebral cortical slices. J Neurochem 60: $780-782$.

Cartmell J, Kemp JA, Alexander SP, Shinozaki H, Kendall DA (1994) Modulation of cyclic AMP formation by putative metabotropic receptor agonists. Br J Pharmacol 111:364-369.

Challis RA, Mistry R, Gray DW, Nahorski SR (1994) Modulatory effects of NMDA on phosphoinositide responses evoked by the metabotropic glutamate receptor agonist IS,3R-ACPD in neonatal rat cerebral cortex. Br J Pharmacol 112:231-239. 
Charpak S, Gähwiler BH (1991) Glutamate mediates a slow synaptic response in hippocampal slice cultures. Proc R Soc Lond [Biol] 243: 221-226.

Charpak S, Gaahwiler BH, Do KQ, Knöpfel T (1990) Potassium conductances in hippocampal neurons blocked by excitatory amino acid transmitters. Nature 347:765-767.

Cherubini E, Ben-Ari Y, Ito S, Krnjevic K (1991) Persistent pulsatile release of glutamate induced by $N$-methyl-D-aspartate in neonatal rat hippocampal neurones. J Physiol (Lond) 436:531-547.

Chinestra P, Aniksztejn L, Diabira D, Ben-Ari Y (1993) RS-methyl-4carboxyphenylglycine neither prevents induction of LTP nor antagonizes metabotropic glutamate receptors in CA1 hippocampal neurons. J Neurophysiol 70:2684-2689.

Chung DS, Winder DG, Conn PJ (1994) 4-Bromohomoibotenic acid selectively activates a 1 aminocyclopentane $1 \mathrm{~S}, 3 \mathrm{R}$-dicarboxylic acidinsensitive metabotropic glutamate receptor coupled to phosphoinositide hydrolysis in rat cortical slices. J Neurochem 63:133-139.

Constanti A, Libri V (1992) Trans-ACPD induces a slow post-stimulus inward tail current $\left(\mathrm{I}_{\mathrm{ADP}}\right)$ in guinea-pig olfactory cortex neurones in vitro. Eur J Pharmacol 216:463-464.

Desai MA, Conn PJ (1991) Excitatory effects of ACPD receptor activation in the hippocampus are mediated by direct effects on pyramidal cells and blockade of synaptic inhibition. J Neurophysiol 66 : $40-52$.

DiFrancesco D (1991) The contribution of the 'pacemaker' current $\left(i_{\mathrm{f}}\right)$ to the generation of spontaneous activity in rabbit sino-atrial node myocytes. J Physiol (Lond) 434:23-40.

Duvoisin RM, Zhang C, Ramonell K (1995) A novel metabotropic glutamate receptor expressed in the retina and olfactory bulb. J Neurosci 15:3075-3083.

Eaton SA, Jane DE, Jones P, Porter RHP, Pook PC-K, Sunter DC, Udvarhelyi PM, Roberts PJ, Salt TE, Watkins JC (1993) Competitive antagonism at metabotropic glutamate receptors by $(S)$-4-carboxyphenylglycine and $R S$-methyl-4-carboxyphenylglycine. Eur J Pharmacol 244:195-197.

Forsythe ID, Clements JD (1990) Presynaptic glutamate receptors depress excitatory monosynaptic transmission hetween mouse hippocampal neurons. J Physiol (Lond) 429:1-16.

Glaum SR, Miller RJ (1993) Activation of metabotropic glutamate receptors produces reciprocal regulation of ionotropic glutamate and GABA responses in the nucleus on the tractus solitarius of the rat. $\mathbf{J}$ Neurosci 13:1636-1641

Greene CC, Schwindt PC, Crill WE (1994) Properties and ionic mechanisms of a metabotropic glutamate receptor-mediated slow afterdepolarization in neocortical neurons. J Neurophysiol 72:693-704.

Hayashi Y, Momiyama A, Takahashi T, Ohishi H, Ogawa-Meguro R, Shigemoto R, Mizuno N, Nakanishi S (1994a) Role of a metabotropic glutamate receptor in synaptic modulation in the accessory olfactory bulb. Nature 366:687-690.

Hayashi Y, Sekiyama N, Nakanishi S, Jane DE, Sunter DC, Birse EF, Udvarhelyi PM, Watkins JC (1994b) Analysis of agonist and antagonist activities of phenylglycine derivatives for different cloned metabotropic glutamate receptor subtypes. J Neurosci 14:3370-3377.

Houamed KM, Kuijper JL, Gilbert TL, Haldeman BA, O'Hara PJ, Mulvihill ER, Almers W, Hagen FS (1991) Cloning, expression, and gene structure of a $G$ protein-coupled glutamate receptor from rat brain. Science 252:1318-1321.

Hubbard JI, Llinás R, Quastel DMJ (1969) Electrophysiological analysis of synaptic transmission. London: Edward Arnold.

Huguenard JR, McCormick DA (1992) Simulation of the currents involved in rhythmic oscillations in thalamic relay neurons. J Neurophysiol 68:1373-1383.

Ishizuka N, Weber J, Amaral DG (1990) Organization of intrahippocampal projections originating from $\mathrm{CA} 3$ pyramidal cells in the rat. J Comp Neurol 295:580-623.

Ito I, Sugiyama H (1991) Roles of glutamate receptors in long-term potentiation at hippocampal mossy fiber synapses. Neuroreport 2:333-336.

Jahnsen H, Llinás RR (1984a) Electrophysiological properties of guinea-pig thalamic neurons: an in vitro study. J Physiol (Lond) 349:205226.

Jahnsen H, Llinás R (1984b) Ionic basis of electroresponsiveness and oscillatory properties of guinea-pig thalamic neurons in vitro. J Physiol (Lond) 349:227-247.

Jane DE, Jones PL, Pook PC-K, Salt TE, Sunter DC, Watkins JC (1993)
Stereospecific antagonism by (+)-methyl-4-carboxyphenylglycine (MCPG) of (1S,3R)-ACPD- induced effects in neonatal rat motoneurons and rat thalamic neurons. Neuropharmacology 32:725-727.

Jonas P, Spruston N (1994) Mechanisms shaping glutamate-mediated excitatory postsynaptic currents in the CNS. Curr Opin Neurobiol $4: 366-372$.

Jones PL, Birse EF, Jane DE, Jones AW, Mewett KN, Pook PC-K, Sunter DC, Udvarhelyi PM, Wharton B, Watkins JC (1993) Agonist and antagonist actions of phenylglycine derivatives at depolarizationmediating (1S,3R)-ACPD receptors in neonatal rat motoneurons. $\mathrm{Br}$ J Pharmacol 108:86.

Leresche N, Jassik-Gershenfeld D, Haby M, Soltesz I, Crunelli V (1990) Pacemaker-like and other types of spontaneous membrane potential oscillations of thalamocortical cells. Neurosci Lett 113:7277.

Lester RA, Jahr CE (1990) Quisqualate receptor-mediated depression of calcium currents in hippocampal neurons. Neuron 4:741-749.

Liu Y-B, Disterhoft JF, Slater NT (1993) Activation of metabotropic glutamate receptors induces long-term depression of GABAergic inhibition in hippocampus. J Neurophysiol 69:1000-1004.

MacVicar BA, Tse FWY (1989) Local neuronal circuitry underlying cholinergic rhythmical slow activity in CA3 area of rat hippocampal slices. J Physiol (Lond) 417:197-212.

Masu M, Tanabe Y, Tsuchida K, Shigemoto R, Nakanishi S (1991) Sequence and expression of a metabotropic glutamate receptor. $\mathrm{Na}$ ture 349:760-765.

McCormick DA, Pape H-C (1990) Properties of a hyperpolarizationactivated cation current and its role in rhythmic oscillations in thalamic relay neurons. J Physiol (Lond) 431:291-318.

McCormick DA, von Krosigk M (1992) Corticothalamic activation modulates thalamic firing through glutamate "metabotropic" receptors. Proc Natl Acad Sci USA 89:2774-2778.

McDonald JW, Schoepp DD (1993) Aminooxyacetic acid produces excitotoxic brain injury in neonatal rats. Brain Res 624:239-244.

Merlin LR, Taylor GW, Wong RKS (1995) Role of metabotropic glutamate receptor subtypes in the patterning of epileptiform activities in vitro. J Neurophysiol 74:896-900.

Miles R, Wong RKS (1986) Excitatory synaptic interactions between CA3 neurons in the guinea-pig hippocampus. J Physiol (Lond) 373: 397418.

Miles R, Poncer J-C (1993) Metabotropic glutamate receptors mediate a post-tetanic excitation of guinea-pig hippocampal inhibitory neurons. J Physiol (Lond) 463:461-473.

Miles R, Wong RKS, Traub RD (1984) Synchronized afterdischarges in the hippocampus: contribution of local synaptic interactions. Neuroscience 12:1179-1189.

Nawy S, Jahr CE (1991) cGMP-gated conductance in retinal bipolar cell is suppressed by the photoreceptor transmitter. Neuron 7:677683.

Ohfune Y, Shimamoto K, Ishida M, Shinozaki H (1993) Synthesis of L-2-(2,3-dicarboxycyclopropyl)glycine: a novel conformationally restricted glutamate analog. Bioorg Med Chem Lett 3:15-18.

Ohishi H, Ogawa-Meguro R, Shigemoto R, Kaneko T, Nakanishi S, Mizuno N (1994) Immunohistochemical localization of metabotropic glutamate receptors, mGluR2 and mGluR3, in rat cerebellar cortex. Neuron 13:55-66.

Pin J-P, Bockaert J (1995) Get receptive to metabotropic glutamate receptors. Curr Opin Neurobiol 5:342-349.

Poncer J-C, Shinozaki H, Miles R (1995) Dual modulation of synaptic inhibition by distinct metabotropic glutamate receptors in the rat hippocampus. J Physiol (Lond) 485:121-134.

Sacaan AI, Schoepn DD (1992) Activation of hippocampal metabotropic excitatory amino acid receptors leads to seizures and neuronal damage. Neurosci Lett 139:77-82.

Schoepp DD, Conn PJ (1993) Metabotropic glutamate receptors in brain function and pathology. Trends Pharmacol Sci 14:13-20.

Schoepp DD, Johnson BG, Monn JA (1992) Inhibition of cyclic AMP formation by a selective metabotropic glutamate receptor agonist. J Neurochem 58:1184-1186.

Schwartzkroin PA, Prince DA (1978) Cellular and field potential properties of epileptogenic hippocampal slices. Brain Res 147:117-130.

Sciancalepore M, Aniksztejn L, Ben-Ari Y, Cherubini E (1993) Repeated applications of 1S,3R-ACPD induce persistent pulsatile release of glutamate from immature hippocampal CA3 neurons. Soc Neurosci Abstr 19:468. 
Sheardown MJ (1992) Metabotropic glutamate receptor agonists reduce epileptiform activity in the rat cortex. Neuroreport 3:916-918.

Shigemoto R, Nakanishi S, Mizuno N (1992) Distribution of the mRNA for a metabotropic glutamate receptor $(\mathrm{mGluR} 1)$ in the central nervous system: an in situ hybridization study in adult and developing rat. J Comp Neurol 322:121-135.

Sladeczek F, Momiyama A, Takahashi T (1993) Presynaptic inhibitory action of a metabotropic glutamate receptor agonist on excitatory transmission in visual cortical neurons. Proc R Soc Lond [Biol] 253: 297-303.

Soltesz I, Lightowler S, Leresche N, Jassik-Gerschenfeld D, Pollard CE, Crunelli V (1991) Two inward currents and the transformation of low-frequency oscillations of rat and cat thalamocortical cells. J Physiol (Lond) 441:175-197.

Steriade M, Deschênes M, Domich L, Mulle C (1985) Abolition of spindle oscillations in thalamic neurons disconnected from nucleus reticularis thalami. J Neurophysiol 54:1473-1497.

Steriade M, Gloor P, Llinás RR, Lopes da Silva FH, Mesulam M-M (1990) Basic mechanisms of cerebral rhythmic activities. Electroencephalogr Clin Neurophysiol 76:481-508.

Steriade M, Nuñez A, Amzica F (1993a) A novel slow $(\ll 1 \mathrm{~Hz}$ ) os cillation of neocortical neurons in vivo: depolarizing and hyperpolarizing components. J Neurosci 13:3252-3265.

Steriade M, Nuñez A, Amzica F (1993b) Intracellular analysis of the relations between the slow $(<1 \mathrm{~Hz})$ neocortical oscillation and other sleep rhythms of the electroencephalogram. J Neurosci 13:32663283 .

Steriade M, Contreras D, Curr'o Dossi R, Nuñez A (1993c) The slow $(<1 \mathrm{~Hz})$ oscillation in reticular thalamic and thalamocortical neurons: scenario of sleep rhythm generation in interacting thalamic and neocortical networks. J Neurosci 13:3284-3299.

Stratton KR, Worley PF. Baraban JM (1990) Pharmacological characterization of phosphoinositide-linked glutamate receptor excitation of hippocampal neurons. Eur J Pharmacol 186:357-361.

Swann JW, Brady RJ, Friedman RJ, Smith EJ (1986) The dendritic origins of penicillin-induced epileptogenesis in CA3 hippocampal pyramidal cells. J Neurophysiol 56:1718-1738.

Swann JW, Smith KL, Brady RJ (1993) Localized excitatory synaptic interactions mediate the sustained depolarization of electrographic seizures in developing hippocampus. J Neurosci 13:4680-4689.

Tanabe Y, Masu M, Takahiro I, Shigemoto R, Nakanishi S (1992) A family of metabotropic glutamate receptors. Neuron 8:169-179.

Tanabe Y, Nomura A, Masu M, Shigemoto R, Mizuno N, Nakanishi S (1993) Signal transduction, pharmacological properties, and expression patterns of two rat metabotropic glutamate receptors, mGluR3 and mGluR4. J Neurosci 13:1372-1378.

Taschenberger H, Roy BL, Lowe DA (1992) Effects of a metabotropic glutamate agonist, trans-ACPD, on cortical epileptiform activity. Neuroreport 3:629-632.
Taylor GW, Wong RKS (1994) Metabotropic agonists promote synchronized oscillations among hippocampal CA3 neurons. Soc Neurosci Abstr 20:399.

Traub RD, Wong RKS (1982) Cellular mechanisms of neuronal synchronization in epilepsy. Science 216:745-747.

Traub RD, Miles R (1991) Neuronal networks of the hippocampus. New York: Cambridge UP.

Traub RD, Miles R, Wong RKS (1987) Models of synchronized hippocampal bursts in the presence of inhibition. I. Single population events. J Neurophysiol 58:739-751.

Traub RD, Wong RKS, Miles R, Michelson H (1991) A model of a CA3 hippocampal pyramidal neuron incorporating voltage-clamp data on intrinsic conductances. J Neurophysiol 66:635-650.

Traub RD, Miles R, Buzsáki G (1992) Computer simulation of carbachol-driven rhythmic population oscillations in the CA3 region of the in vitro rat hippocampus. J Physiol (Lond) 451:653-672.

Trombley PQ, Westbrook GL (1992) L-AP4 inhibits calcium currents and synaptic transmission via a G-protein-coupled glutamate receptor. J Neurosci 12:2043-2050.

von Krosigk M, Bal T, McCormick DA (1993) Cellular mechanisms of a synchronized oscillation in the thalamus. Science 261:361-364.

Wang X-J, Rinzel J (1993) Spindle rhythmicity in the reticularis thalami nucleus: synchronization among mutually inhibitory neurons. Neuruscience 53:899-904.

Watkins J, Collingridge G (1994) Phenylglycine derivatives as antagonists of metabotropic glutamate receptors. Trends Pharmacol Sci 15 : $332-342$.

Westbrook GL (1994) Glutamate receptor update. Curr Opin Neurobiol 4:337-346

Whittington MA, Traub RD, Jefferys JG (1995) Synchronized oscillations in interneuron networks of driven by metabotropic glutamate receptor activation. Nature 373:612-616

Winder DG, Conn PJ (1992) Activation of metabotropic glutamate receptors in the hippocampus increases cyclic AMP accumulation. J Neurochem 59:375 378.

Wong RKS, Miles R (1993) Study of GABAergic inhibition and GABA-A receptors in experimental epilepsy. In: Epilepsy. Models, mechanisms and concepts (Schwarlzkroin PA, ed), pp 424-436. New York: Cambridge UP.

Wong RKS, Traub RD (1983) Synchronized burst discharge in disinhibited hippocampal slice. I. Initiation in CA2-CA3 region. J Neurophysiol 49:442-458.

Zheng F, Gallagher JP (1991) Trans-ACPD (trans-D,L-1-amino-1,3-cyclopentanedicarboxylic acid) elicited oscillation of membrane potentials in rat dorsolateral septal nucleus neurons recorded intracellularly in vitro. Neurosci Lett 125:147-150.

Zheng F, Gallagher JP (1992) Metabotropic glutamate receptor agonists potentiate a slow afterdepolarization in CNS neurons. Neuroreport $3: 622-624$. 